OPEN ACCESS

Edited by:

Jörg Stülke,

University of Göttingen, Germany

Reviewed by:

Theresa M Koehler, University of Texas Health Science

Center at Houston, United States

Claes Von Wachenfeldt,

Lund University, Sweden

${ }^{*}$ Correspondence:

Annette Fagerluna

annette.fagerlund@nofima.no

Ole Andreas Økstad

aloechen@farmasi.uio.no

Specialty section:

This article was submitted to Microbial Physiology and Metabolism,

a section of the journa

Frontiers in Microbiology

Received: 26 September 2020 Accepted: 01 December 2020

Published: 23 December 2020

Citation:

Smith $V$, Josefsen $M$, Lindbäck T,

Hegna IK, Finke S, Tourasse NJ,

Nielsen-LeRoux C, Økstad OA and

Fagerlund $A$ (2020) MogR Is

a Ubiquitous Transcriptional Repressor Affecting Motility, Biofilm Formation and Virulence in Bacillus thuringiensis.

Front. Microbiol. 11:610650 doi: 10.3389/fmicb.2020.610650

\section{MogR Is a Ubiquitous Transcriptional Repressor Affecting Motility, Biofilm Formation and Virulence in Bacillus thuringiensis}

\author{
Veronika Smith',2, Malin Josefsen ${ }^{1}$, Toril Lindbäck ${ }^{3}$, Ida K. Hegna', Sarah Finke ${ }^{1,2}$, \\ Nicolas J. Tourasse ${ }^{4}$, Christina Nielsen-LeRoux ${ }^{5}$, Ole Andreas Økstad ${ }^{1,2 *}$ and \\ Annette Fagerlund ${ }^{1,6 *}$
}

' Laboratory for Microbial Dynamics (LaMDa), Section for Pharmacology and Pharmaceutical Biosciences, Department of Pharmacy, University of Oslo, Oslo, Norway, ${ }^{2}$ Centre for Integrative Microbial Evolution (CIME), Faculty of Mathematics and Natural Sciences, University of Oslo, Oslo, Norway, ${ }^{3}$ Department of Paraclinical Sciences, Faculty of Veterinary Medicine, Norwegian University of Life Sciences, Oslo, Norway, ${ }^{4}$ CNRS, INSERM, ARNA, UMR 5320, U1212, University of Bordeaux, Bordeaux, France, ${ }^{5}$ INRAE, AgroParisTech, Micalis, Paris-Saclay University, Jouy-en-Josas, France, ${ }^{6}$ Nofima, Norwegian Institute of Food, Fisheries and Aquaculture Research, Ås, Norway

Flagellar motility is considered an important virulence factor in different pathogenic bacteria. In Listeria monocytogenes the transcriptional repressor MogR regulates motility in a temperature-dependent manner, directly repressing flagellar- and chemotaxis genes. The only other bacteria known to carry a mogR homolog are members of the Bacillus cereus group, which includes motile species such as B. cereus and Bacillus thuringiensis as well as the non-motile species Bacillus anthracis, Bacillus mycoides and Bacillus pseudomycoides. Furthermore, the main motility locus in B. cereus group bacteria, carrying the genes for flagellar synthesis, appears to be more closely related to $L$. monocytogenes than to Bacillus subtilis, which belongs to a separate phylogenetic group of Bacilli and does not carry a mogR ortholog. Here, we show that in $B$. thuringiensis, MogR overexpression results in non-motile cells devoid of flagella. Global gene expression profiling showed that 110 genes were differentially regulated by MogR overexpression, including flagellar motility genes, but also genes associated with virulence, stress response and biofilm lifestyle. Accordingly, phenotypic assays showed that MogR also affects cytotoxicity and biofilm formation in B. thuringiensis. Overexpression of a MogR variant mutated in two amino acids within the putative DNA binding domain restored phenotypes to those of an empty vector control. In accordance, introduction of these mutations resulted in complete loss in MogR binding to its candidate flagellar locus target site in vitro. In contrast to $L$. monocytogenes, MogR appears to be regulated in a growth-phase dependent and temperature-independent manner in $B$. thuringiensis 407 . Interestingly, $\operatorname{mog} R$ was found to be conserved also in non-motile $B$. cereus group species such as $B$. mycoides and $B$. pseudomycoides, which both carry major gene deletions in the flagellar motility locus and where 


\begin{abstract}
in $B$. pseudomycoides mogR is the only gene retained. Furthermore, mogR is expressed in non-motile $B$. anthracis. Altogether this provides indications of an expanded set of functions for MogR in B. cereus group species, beyond motility regulation. In conclusion, MogR constitutes a novel $B$. thuringiensis pleiotropic transcriptional regulator, acting as a repressor of motility genes, and affecting the expression of a variety of additional genes involved in biofilm formation and virulence.
\end{abstract}

Keywords: Bacillus cereus group, MogR, motility regulator, virulence, biofilm

\section{INTRODUCTION}

In many bacterial species, flagella have been demonstrated to be important to virulence functions, including reaching the optimal host site, colonization or invasion, maintenance at the infection site, post-infection dispersal, protein secretion and more (Chaban et al., 2015). Temperature-dependent regulation of motility in the human pathogen Listeria monocytogenes has been described in a series of studies published by Higgins and co-workers, in which motility was shown to be regulated by the transcriptional repressor $\mathrm{MogR}$ and its anti-repressor GmaR (Gründling et al., 2004; Shen and Higgins, 2006; Shen et al., 2006; Kamp and Higgins, 2009; Shen et al., 2009; Kamp and Higgins, 2011), the genes for which are widely distributed among different Listeria spp. (Smith and Hoover, 2009). L. monocytogenes is a foodborne facultative intracellular pathogen, which uses flagellum-based motility when present in its extracellular environmental niche. During mammalian infection however, motility genes are downregulated by MogRdependent repression upon sensing of mammalian physiological temperature $\left(37^{\circ} \mathrm{C}\right.$ in the human). In this system, the GmaR antirepressor functions as the temperature sensor, by antagonizing MogR repression activity at temperatures below $37^{\circ} \mathrm{C}$ (Shen et al., 2006). The activity of $\mathrm{GmaR}$ is dependent on the transcriptional activation by DegU at low temperatures, and a temperature-dependent, post-transcriptional mechanism limits GmaR production to temperatures below $37^{\circ} \mathrm{C}$ (Kamp and Higgins, 2009). This system allows L. monocytogenes to switch from an environmental and extracellular motile bacterium to an intracellular pathogen. Inside host cells, flagella are not required as L. monocytogenes cells instead move by actin-based motility, and downregulation of flagella during infection is thought to aid bacterial evasion of the host innate immune system (Hayashi et al., 2001; Li et al., 2017).

The only other known bacteria carrying a homolog to Listeria spp. $\operatorname{mog} R$ are species from the Bacillus cereus group (B. cereus sensu lato) (Gründling et al., 2004; Fagerlund et al., 2010), which is a group of closely related Gram-positive spore-forming bacteria of considerable medical and economic importance. The group comprises at least seven species, including B. cereus (B. cereus sensu stricto), Bacillus anthracis, Bacillus thuringiensis, Bacillus weihenstephanensis, Bacillus mycoides, Bacillus pseudomycoides, and Bacillus cytotoxicus, which, like L. monocytogenes, can be isolated from the environment, e.g., soil, air and water. In contrast to L. monocytogenes however, B. cereus is an extracellular opportunistic pathogen. The majority of strains of $B$. cereus sensu stricto, B. thuringiensis, B. weihenstephanensis and B. cytotoxicus are motile by peritrichous flagella, while B. anthracis, B. mycoides, and $B$. pseudomycoides are described as non-motile (Twine et al., 2009; Guinebretière et al., 2013). Many strains belonging to the B. cereus group can cause foodborne disease (emetic or diarrheal syndrome) and serious opportunistic infections in man, but the group also encompasses strains that are used as probiotics (Stenfors Arnesen et al., 2008; Bottone, 2010; Cutting, 2011), some of which have been suggested to have separate species status (e.g., Bacillus toyonensis; Jiménez et al., 2013). The highly virulent mammalian pathogen $B$. anthracis is the cause of anthrax disease, being endemic in several parts of the world, and has been used as a biological terror agent. B. thuringiensis is an entomopathogenic bacterium, frequently used as a biopesticide to protect crops against insect pests, however this species also carries virulence factors shared with $B$. cereus sensu stricto (Damgaard, 1995; Gaviria Rivera et al., 2000; Swiecicka et al., 2006; Celandroni et al., 2014; Kim et al., 2015) and has caused human infections similar to those caused by B. cereus (Samples and Buettner, 1983; Jackson et al., 1995; Damgaard et al., 1997; Hernandez et al., 1998; Ghelardi et al., 2007b). Although strains in the B. cereus group to a certain degree follow ecological diversification patterns through evolutionary time (Guinebretière et al., 2008), B. cereus and $B$. thuringiensis isolates are intermingled in global MLST- or $k$-mer-based phylogenetic analyses (based on the phylogenetic analysis of common housekeeping genes, or the presence of subsequences of length $k$ in a genome, respectively) of a high number of non-biased isolates (Kolstø et al., 2009; Bazinet, 2017), while the thermotolerant species B. cytotoxicus forms a separate and phylogenetically remote clade within the $B$. cereus group population.

The bacterial flagellum is a complex molecular structure made up of about 25 different proteins. In most bacteria studied to date, expression of flagellar genes is subject to hierarchical regulation to ensure the sequential expression required for proper flagellum assembly (Smith and Hoover, 2009; Erhardt et al., 2010). In contrast, L. monocytogenes and B. cereus group strains appear to lack this transcriptional cascade control of flagellar biosynthesis (Smith and Hoover, 2009; Chiara et al., 2015). B. cereus group bacteria also lack $\sigma^{D}$, a common key regulator of motility genes in bacteria, indicating a different mode of transcriptional regulation for the motility genes. In this study, we aimed to investigate functional roles of the MogR homolog identified in B. cereus group bacteria, and whether motility regulation in the $B$. cereus group more closely resembles that of $L$. monocytogenes rather than other Bacillus species. 


\section{MATERIALS AND METHODS}

\section{Sequence Analysis}

Motility proteins that were orthologs between species were identified by amino acid sequence searches (BLASTP) performed using BLAST v.2.6.0 + (Altschul et al., 1990, 1997) between all pairwise combinations of the motility loci from B. thuringiensis 407, L. monocytogenes EGD-e, and B. subtilis 168 (RefSeq accession numbers NC_018877.1, NC_003210.1, and NC_000964.3, respectively; Glaser et al., 2001; Barbe et al., 2009; Sheppard et al., 2013). Results for reciprocal best BLASTP hits between each pair were included in Supplementary Table 1 if the BLASTP alignments had a percentage of identical matches above $20 \%$, a bit score greater than 30 and covered at least $25 \%$ of each amino acid sequence. Comparisons between the motility locus in different $B$. cereus group strains were obtained using the Integrated Microbial Genomes (IMG) browser (Markowitz et al., $2010^{1}$ ), by searching for orthologous genome neighborhoods to genes from the $B$. thuringiensis 407 motility operon. Annotations for the B. cereus ATCC 10987 motility cluster and the B. mycoides DSM 2048 mogR gene were corrected using EasyGene (Larsen and Krogh, 2003). To perform an exhaustive comparative analysis of the genetic structure of the motility locus, genome sequences of 106 subgroup I strains of the $B$. cereus group that had been sequenced to a minimum of scaffold level were downloaded from NCBI (November 25, 2019), and a local BLAST database was indexed from the corresponding subgroup I proteomes. The corresponding protein sequence from each of the 50 genes in the main B. thuringiensis 407 motility locus (genes with locus tags ranging from AFV17362.1 to AFV17411.1, found within coordinates 1608289 to 1653756 in the closed B. thuringiensis 407 genome sequence, accession number CP003889) were used as queries in BLASTP searches (parameters: -num_threads 10 -evalue 1.0e-05 -seg no -outfmt 0 ) for homologous proteins among the subgroup I strains. Output files were parsed using custom-made shell scripts, and sed/awk. Candidate MogR binding sites in the B. thuringiensis 407 genome were identified by searching the intergenic regions upstream of candidate genes using CLC Main Workbench (Qiagen), with the L. monocytogenes consensus MogR binding sequence (TTTTWWNWWAAAA [IUPAC nucleotide codes]; Shen et al., 2009) as query, allowing for up to two mismatches to identify candidate hits.

\section{Strains and Growth Conditions}

The strains used in this study are presented in Table $\mathbf{1}$. B. thuringiensis $407 \mathrm{Cry}^{-}$(also sometimes referred to as $\mathrm{Bt} 407$ ) is an acrystalliferous strain cured of its cry plasmid (Lereclus et al., 1989). It is genetically close to the B. cereus type strain ATCC 14579 (Tourasse et al., 2006).

Unless otherwise stated, B. thuringiensis 407 cultures were inoculated with $1 \%$ of an overnight culture and grown at $30^{\circ} \mathrm{C}$ and $200 \mathrm{rpm}$ in Luria Bertani (LB) broth or in bactopeptone medium ( $1 \% \mathrm{w} / \mathrm{v}$ bactopeptone, $0.5 \% \mathrm{w} / \mathrm{v}$ yeast extract, $1 \% \mathrm{w} / \mathrm{v}$ $\mathrm{NaCl})$. For cloning and expression in Escherichia coli, ampicillin at 50 or $100 \mu \mathrm{g} \mathrm{mL}^{-1}$, kanamycin at $50 \mu \mathrm{g} \mathrm{mL}-1$ and/or erythromycin at $400 \mu \mathrm{g} \mathrm{mL}^{-1}$ was used. Erythromycin at $10 \mu \mathrm{g}$ $\mathrm{mL}^{-1}$ was used to maintain the $\mathrm{pHT} 304-\mathrm{P}_{x y l}$ plasmid constructs in B. thuringiensis 407. For induction of gene expression from the xylA promoter on $\mathrm{pHT} 304-\mathrm{P}_{x y l}$, xylose was added to the growth medium at $1 \mathrm{mM}$ or as otherwise stated. For induction of MBP-MogR in E. coli BL21(DE3), $0.3 \mathrm{mM}$ isopropyl- $\beta$-Dthiogalactopyranoside (IPTG) was used. Growth curves were prepared in bactopeptone medium, $\mathrm{pH} 7.0$ with cultures grown with shaking at $220 \mathrm{rpm}$, using $50 \mathrm{~mL}$ culture volumes in $250 \mathrm{~mL}$ baffled flasks.

\section{Reverse Transcription Quantitative PCR (RT-qPCR)}

For analysis of $\operatorname{mog} R, f l a A$ and $f l a B$ expression throughout the bacterial growth phase, RT-qPCR was performed essentially as described by Fagerlund et al. (2016). Briefly, cells grown in bactopeptone medium at $30^{\circ} \mathrm{C}$ were incubated in an equal volume of ice-cold methanol for $5 \mathrm{~min}$ before harvesting by centrifugation. Cells were lysed using a Precellys 24 Tissue Homogenizer (Bertin) and RNA was isolated using the RNeasy Mini or Midi Kits (Qiagen). After treatment with DNase and further purification, cDNA synthesis was performed in duplicate for each sample using SuperScript III Reverse Transcriptase (Invitrogen). For all samples, a negative control reaction without reverse transcriptase was included. RT-qPCR was carried out with a LightCycler 480 Real-Time PCR System (Roche) using primers listed in Supplementary Table 2. The three genes gatB, $r p s U$, and $u d p$, shown to be stably expressed throughout the B. cereus life cycle (Reiter et al., 2011), were used as reference genes, and were included for each sample and on each plate. The second derivative maximum method in the LightCycler 480 software (Roche) was utilized to obtain a quantification cycle (Cq) value for each reaction. The expression of each target gene in each biological replicate was converted into $\mathrm{E}^{C q}$ values (Pfaffl, 2001) and then normalized to the geometric mean of the $E^{C q}$ values obtained for the three reference genes. Finally, averages and standard deviations were calculated from the normalized expression values from the biological replicates.

For analysis of $f l a A$ and $f l a B$ expression in the B. thuringiensis 407 strains overexpressing MogR and $\operatorname{Mog} \mathrm{R}^{Q N \rightarrow A A}$ (see below), the same procedure was used except that $g a t B$ and $r p s U$ were used as reference genes.

\section{Cloning of $\boldsymbol{m o g} R$ for Expression in B. thuringiensis 407}

The low-copy number E. coli/Bacillus shuttle vector $\mathrm{pHT} 304-\mathrm{P}_{x y l}$, in which $x y l R$ and the $x y l A$ promoter from B. subtilis was inserted into the pHT304 cloning site (Arantes and Lereclus, 1991) allowing xylose-inducible expression of downstream cloned genes, was used for overexpression studies. The sequence encoding MogR from B. thuringiensis 407 (BTB_RS08390) was PCR-amplified using primers 5 -gtcggatccgaattgtgaaaggatgagg$3^{\prime}$ and $5^{\prime}$-taaggtacctcttccttcttcggaacg- $3^{\prime}$ and genomic DNA as the template. The PCR product was inserted into pHT304$\mathrm{P}_{x y l}$ using the primer-incorporated BamHI and KpnI restriction 
sites (underlined), creating pHT304- $\mathrm{P}_{x y l}$ - $\operatorname{mog} R$ and placing $\operatorname{mog} R$ under transcriptional control of the $x y l A$ promoter.

The plasmid $\mathrm{pHT} 304-\mathrm{P}_{x y l}-\operatorname{mog} R^{Q N \rightarrow A A}$, containing $\operatorname{mog} R$ with amino acid substitutions in two of the six conserved amino acid residues predicted to make basespecific contacts with the MogR recognition site (Shen et al., 2009) was created by site-directed mutagenesis of pHT304- $\mathrm{P}_{x y l}-\operatorname{mog} R$ using the QuikChange II SiteDirected Mutagenesis Kit (Stratagene) and primers $5^{\prime}$-tccaaaaacagaaagtcaattggcagctacgtattataaattgaaaaaacgtg- $3^{\prime}$

and $\quad 5^{\prime}$-cacgttttttcaatttataatacgtagctgccaattgactttctgttttgga- $3^{\prime}$ (mutated bases underlined). The introduced mutations were Q119A and N120A.

The plasmids were verified by sequencing. The constructed pHT304- $\mathrm{P}_{x y l}$ plasmids and the empty vector were introduced by electroporation into B. thuringiensis 407 (Masson et al., 1989).

\section{Motility Assay}

Swimming ability was determined on $0.3 \%$ LB soft agar plates with $1 \mathrm{mM}$ xylose and $10 \mu \mathrm{g} \mathrm{mL}^{-1}$ erythromycin added. A $5 \mu \mathrm{L}$ drop of culture grown in LB broth overnight at $30^{\circ} \mathrm{C}$ was spotted on each agar plate. The plates were wrapped in plastic and incubated for $7 \mathrm{~h}$ at $30^{\circ} \mathrm{C}$. Each independent assay was performed with two or three technical replicates.

\section{Atomic Force Microscopy (AFM)}

Atomic force microscopy imaging and analysis was performed using a Nanowizard AFM microscope (JPK Instruments). Bacterial cell culture was grown in LB broth with erythromycin $\left(10 \mu \mathrm{g} \mathrm{mL}^{-1}\right)$ and xylose $(10 \mathrm{mM})$ at $37^{\circ} \mathrm{C}$ to an $\mathrm{OD}_{600}$ of 3 . One $\mathrm{mL}$ of culture was washed three times and finally resuspended in $0.9 \% \mathrm{NaCl}$. Cells were then diluted (15:50) in a $10 \mathrm{mM}$ magnesium/Tris buffer, $\mathrm{pH}$ 7.5. Ten $\mu \mathrm{L}$ was applied onto freshly cleaved mica surfaces mounted on a glass slide, and allowed to adhere for $10 \mathrm{~min}$ followed by washing $(10 \times 100 \mu \mathrm{L})$ using sterile $\mathrm{dH}_{2} \mathrm{O}$. Excess water was carefully removed, and the slide gently dried using a nitrogen gas jet stream. Images were recorded in intermittent-contact mode at room temperature in air using a MicroMasch NSC35/AIBS cantilever. AFM images were analyzed using The NanoWizard IP Image Processing Software (JPK Instruments).

\section{SDS-PAGE and Western Immunoblotting}

For detection of flagellin, for each strain analyzed, two parallel bacterial culture samples (10 $\mathrm{mL} \mathrm{LB}$ broth) were harvested by centrifugation $\left(4100 \times g, 4^{\circ} \mathrm{C}\right)$ after $3.5 \mathrm{~h}$ growth at $30^{\circ} \mathrm{C}\left(\mathrm{OD}_{600}\right.$ $\sim 1.2$ ) - one for extraction of surface proteins, and one for whole cell protein extraction. The cell pellets were resuspended in $1 \mathrm{~mL}$ PBS (pH 7.1) and kept on ice. For extraction of surface proteins, the washed cells were centrifuged for $5 \mathrm{~min}$ at $16,000 \times g$ and $4^{\circ} \mathrm{C}$ and resuspended in an equal volume of $2 \times$ SDS-PAGE sample buffer before incubation at $95^{\circ} \mathrm{C}$ for $5 \mathrm{~min}$. The supernatant was collected by centrifugation as before. The whole cell fraction was prepared by washing the cell pellet in PBS followed by centrifugation for $5 \mathrm{~min}$ at $16,000 \times g$ and $4^{\circ} \mathrm{C}$. The pellet was then resuspended in $500 \mu \mathrm{L}$ PBS and lysed using a Precellys 24 Tissue Homogenizer (Bertin). The supernatant was collected by centrifugation for $8 \mathrm{~min}$ as before. Whole cell supernatant $(21 \mu \mathrm{L})$ with $7 \mu \mathrm{L} 4 \times$ SDS-PAGE buffer and $5 \mu \mathrm{L}$ of the surface protein fraction were separated on 12\% SDS-PAGE gels as described below.

For detection of $\mathrm{Hbl}$, Nhe and $\mathrm{CytK}$, cultures were harvested after $4.5 \mathrm{~h}$ growth. Supernatant samples were collected by centrifugation, concentrated 40 -fold by precipitation with four volumes of ice-cold acid acetone:methanol $(1: 1 \mathrm{v} / \mathrm{v})$, stored at $-20^{\circ} \mathrm{C}$ overnight, and harvested by centrifugation for $30 \mathrm{~min}$ at $16,000 \times g$ and $4^{\circ} \mathrm{C}$. Then, pellets were left to evaporate at $4^{\circ} \mathrm{C}$ overnight and resuspended in $2 \times$ SDS-PAGE sample buffer. Samples were diluted 20-fold with $\mathrm{MQ} \mathrm{H}_{2} \mathrm{O}$. Concentrated supernatant samples $(10 \mu \mathrm{L})$ were separated on $10 \%$ SDSPAGE gels.

SDS-PAGE was carried out using a Bio-Rad Mini-Protean II Dual Slab Cell, using $10 \mu \mathrm{L}$ Prestained Protein Marker, Broad range (New England Biolabs) as the molecular weight marker. Western blot analysis was performed using Immun-Blot PVDF membranes (Bio-Rad) according to standard protocols (Harlow, 1988). Blocking was performed for $1 \mathrm{~h}$ in $5 \%$ non-fat dry milk in TBST. Flagellin proteins were detected using a rabbit antiserum raised against flagellin from Bacillus mojavensis, used at a 1:300 dilution, and a HRP-conjugated donkey-anti-rabbit antibody (Santa Cruz Biotechnology) diluted 1:10,000 as secondary antibody. CytK was detected using rabbit antiserum (Fagerlund et al., 2004) diluted 1:2000, followed by an HRP-conjugated donkey anti-rabbit antibody (Santa Cruz Biotechnology) diluted 1:5000. Hbl B and NheA were detected using monoclonal antibodies $2 \mathrm{~A} 3$ against $\mathrm{Hbl} \mathrm{B}$ (Dietrich et al., 1999) and 1A8 against NheA (Dietrich et al., 2005) (both diluted 1:15), followed by HRP-conjugated AffiniPure Goat-anti-mouse $\operatorname{IgG}(\mathrm{H}+\mathrm{L})$ (Jackson Immuno Research Laboratories) at $80 \mu \mathrm{g}$ $\mathrm{mL}^{-1}$. SuperSignal West Femto Substrate (Pierce) was used to develop the blots. Western blots were photographed in a Chemi Genius Bio Imaging System (Syngene), and sub-saturation images were saved as jpeg files in ImageJ (Abràmoff et al., 2004).

\section{Microarray Analysis}

Cultures of B. thuringiensis 407 harboring either $\mathrm{pHT} 304-\mathrm{P}_{x y l}$ or pHT304- $\mathrm{P}_{x y l}-\operatorname{mog} R$ were grown in LB broth containing $10 \mathrm{mM}$ xylose at $37^{\circ} \mathrm{C}$ for $3 \mathrm{~h}$, and then incubated in an equal volume of ice-cold methanol for $5 \mathrm{~min}$ before pellets were harvested by centrifugation at $2800 \times g$ for $20 \mathrm{~min}$. For extraction of RNA, cells were lysed using a Precellys 24 Tissue Homogenizer (Bertin) and RNA was isolated using the RNeasy Mini Kit (Qiagen) and subjected to on-column DNase-treatment using the RNase-Free DNase Set (Qiagen). cDNA synthesis, labeling and purification was performed as described (Gohar et al., 2008). Microarray slides were printed at The Microarray core facility of the Norwegian University of Science and Technology (NTNU). Design, printing, prehybridization, hybridization and scanning of the slides and analysis of the data was performed as described (Gohar et al., 2008). Each microarray experiment was based on four slides, all biological replicates. $P$-values were computed using a false discovery rate (FDR) of 0.05 .

The microarray slides contain 70-mer oligonucleotide probes designed to detect open reading frames (ORFs) in the following 
strains: B. anthracis Ames, B. anthracis A2012, and B. cereus ATCC 14579, in addition to selected genes from B. cereus ATCC 10987 (Kristoffersen et al., 2007). All probe sequences on the microarray were analyzed by BLAST for hits to the annotated genes of a $B$. thuringiensis $407 \mathrm{draft}$ genome sequence (as of April 30, 2009; the gene lists are based on the GenBank annotations as of this date; accession no. ACMZ00000000.1). Only probes with $93 \%$ identity or greater to a transcript/feature sequence of $B$. thuringiensis 407 were included in the analysis. Of the predicted $B$. thuringiensis 407 genes, 1719 genes, most of which were hypothetical genes, did not have corresponding probes on the array (these include the 761 genes on contigs 00213 and 00060 , which appear to be plasmid-borne). COG categories were obtained for the analyzed genes as reported in the IMG database ${ }^{1}$.

\section{Cytotoxicity Assay}

The Vero cell cytotoxicity assay was performed as described by Lindbäck and Granum (2006), and measures the percentage inhibition of $\mathrm{C}^{14}$-leucine incorporation in cells due to the cells being subjected to toxins, calculated relative to a negative control where cells were not subjected to toxin sample. Samples of early stationary phase cultures grown to an $\mathrm{OD}_{600}$ of 2.4 were collected and $100 \mu \mathrm{L}$ or $150 \mu \mathrm{L}$ samples (for deletion mutants and overexpression strains, respectively) were applied to the cytotoxicity assay. The assays were performed for three independent biological replicates with two technical replicates in each assay.

\section{Virulence in Galleria mellonella Larvae}

The virulence-related properties of MogR were assessed by comparing the killing effect of the B. thuringiensis $407 \mathrm{MogR}$ overexpression and empty vector control (pHT304- $\mathrm{P}_{x y l}$ plasmid) strains, in both wild type and $\triangle$ flaAB backgrounds, by infection (force feeding) in fifth instar Galleria mellonella larvae. G. mellonella eggs were hatched at $28^{\circ} \mathrm{C}$ and the larvae reared on beeswax and pollen. For infection experiments, groups of 20 to 25 G. mellonella larvae, weighing about $200 \mathrm{mg}$ each, were used. As MogR overexpression is activated from the pHT304$\mathrm{P}_{x y l}$ promoter by the addition of xylose, we tried for the first time to evaluate if activation could occur in the insect intestine as well. Therefore, xylose $(20 \mathrm{mM})$ was both added to the LB growth medium of the four strains, as well as to the bacterial inoculums and the toxin alone control (Cry1C) at time zero (time point of force feeding). Larvae were force fed a second time with $10 \mu \mathrm{L} 20 \mathrm{mM}$ xylose $5 \mathrm{~h}$ later (in order to again activate MogR expression from the plasmid). Infections were otherwise performed as previously described (Fedhila et al., 2006), by force feeding with $10 \mu \mathrm{L}$ of a mixture containing $4-5 \times 10^{6}$ of vegetative bacteria (exponential growth $\mathrm{OD}_{600} \sim 1$ in $\mathrm{LB}$ ) with $20 \mathrm{mM}$ xylose and $3 \mu \mathrm{g}$ of activated Cry1C toxin to overcome the $B$. thurinngiensis 407 strain being cry negative. The larvae in the control group were fed PBS buffer or Cry1C toxin and xylose in corresponding amounts to the samples containing bacterial

${ }^{1}$ http://img.jgi.doe.gov inocula. The chosen dose was expected to result in about $70 \%$ $( \pm 5 \%)$ mortality at $37^{\circ} \mathrm{C}$ after $48 \mathrm{~h}$.

\section{Biofilm Assays}

The ability to form biofilms was determined using a glass tube screening assay (Houry et al., 2010). Briefly, exponential phase cultures were diluted into HCT medium (Lecadet et al., 1980; Lereclus et al., 1982) to an $\mathrm{OD}_{600}$ of 0.01 , and $2 \mathrm{~mL}$ was inoculated into sterile $6 \mathrm{~mL}$ glass tubes. The tubes were incubated for $72 \mathrm{~h}$ at $37^{\circ} \mathrm{C}$. The biofilm was subsequently collected by removing the culture medium with a Pasteur pipette and thoroughly vortexing in $2 \mathrm{~mL}$ PBS before measuring the $\mathrm{OD}_{600}$ of the suspension of biofilm cells. Each strain was tested in five biological replicates, each with 3 or 4 technical replicates.

The ability to form biofilms in polyvinylchloride (PVC) microtiter plates was determined using a crystal violet biofilm screening assay (Auger et al., 2006). Briefly, fresh bactopeptone medium was inoculated with $0.5 \%$ exponential phase culture, transferred to 96-well plates (Falcon \#353911) and incubated for 24, 48 and $72 \mathrm{~h}$ at $30^{\circ} \mathrm{C}$. The biofilm was subsequently washed using PBS, stained using $0.3 \%$ crystal violet, washed as before, solubilized with acetone:methanol $(1: 3 \mathrm{v} / \mathrm{v})$, and transferred to flat-bottomed microtiter plates (Falcon \#353915) for determination of the absorbance of the solubilized dye at $570 \mathrm{~nm}$. Each strain was tested in triplicate. Statistical analyses were performed separately for each time point, as described under "Statistical analyses" below.

\section{Expression of MBP-Tagged MogR in E. coli}

The sequence encoding MogR from $B$. thuringiensis 407 (BTB_RS08390) was PCR amplified using primers $\quad 5^{\prime}$-atgtatcaccacacagcaattaatgtattag- $3^{\prime}$ and $5^{\prime}$ gcgcggatccttattactgtgttacggtcataacttgtcc $-3^{\prime}$ and genomic DNA as the template. The PCR product was cloned into the pMAL-p5x vector (New England Biolabs) using the XmnI and BamHI restriction sites (underlined) according to the manufacturer's instructions, allowing expression of MBP-MogR. A construct expressing the MBP-MogR $\mathrm{R}^{Q N \rightarrow A A}$ protein was created by sitedirected mutagenesis of pMAL-p5x-mogR using the QuikChange II Site-Directed Mutagenesis Kit (Stratagene) with the same primers as for $\mathrm{pHT} 304-\mathrm{P}_{x y l}-\mathrm{Mog} \mathrm{R}^{Q N \rightarrow A A}$. Constructs were transformed into E. coli BL21(DE3) cells. The plasmids were verified by sequencing. MBP-MogR and $\mathrm{MBP}-\mathrm{Mog} \mathrm{R}^{\mathrm{QN}} \rightarrow A A$ proteins were expressed in E. coli BL21(DE3) and purified using the manufacturer's manual "Method I - Total cell extract". In short, $100 \mathrm{~mL} \mathrm{LB}$ broth was inoculated with a $1 \mathrm{~mL}$ overnight culture containing cells harboring fusion plasmid. Cells were grown at $37^{\circ} \mathrm{C}$ with shaking to an $\mathrm{OD}_{600}$ of $\sim 0.5$. IPTG was added to a final concentration of $0.3 \mathrm{mM}$ and cells were induced for $2 \mathrm{~h}$. The cells were harvested by centrifugation at $4500 \times g$ for $10 \mathrm{~min}$ and frozen at $-20^{\circ} \mathrm{C}$ overnight, sonicated in an ice-water bath, and then centrifuged at 20,000 $\times g$ for $20 \mathrm{~min}$ at $4^{\circ} \mathrm{C}$. The supernatants were diluted 1:6 in Column Buffer 
(20 mM Tris-HCl, 200 mM NaCl, 1 mM EDTA). MBP-MogR proteins were purified by amylose affinity chromatography (Poly-Prep Chromatography column, $0.8 \times 4 \mathrm{~cm}$, Bio-Rad). The identity and purity of proteins was confirmed by SDSPAGE (Coomassie stain) and the quantity determined by Bradford assay (Pierce BCA Protein Assay Kit, Thermo Fisher).

\section{Electrophoretic Mobility Shift Assay (EMSA)}

DNA fragments were generated by PCR using chromosomal DNA from B. thuringiensis 407 as template and the following primer combinations: $5^{\prime}$ cgggtgtcaactaaaaattcg- $3^{\prime} / 5^{\prime}$-caactatcataatatcaccttttcgg- $3^{\prime} \quad$ (fla), $5^{\prime}$-ttacagaaatgaaatttacggataac- $3^{\prime} / 5^{\prime}$-ccttatcctttctgtctggtc- $3^{\prime}(\mathrm{hbl})$, and $\quad 5^{\prime}$-tccgtatgtaattccgtttcaaga- $3^{\prime} / 5^{\prime}$-aatttcctgcttgaccctt- $3^{\prime}$ (ctrl1). Corresponding $5^{\prime}$ biotinylated probes were generated for the $f l a$ and $h b l$ fragments using biotin-labeled primers. The ctrl1 fragment was chosen as a non-specific competitor control for binding to $B$. thuringiensis DNA and is a PCR product from inside a randomly chosen gene from B. thuringiensis 407 (BTB_RS08990 encoding an elongation factor G-binding protein). A commercial EMSA kit (LightShift Chemiluminescent, Thermo Scientific) was used to detect binding of MogR protein to DNA following the manufacturer's instructions. Unlabeled Epstein Barr nuclear antigen DNA supplied with the kit was used as non-Bacillus non-specific competitor DNA control (ctrl2 fragment). DNA binding reactions were conducted in $20 \mu \mathrm{L}$ volumes containing $10 \mathrm{mM}$ Tris- $\mathrm{HCl} \mathrm{pH} \mathrm{7.5,} 50 \mathrm{mM} \mathrm{KCl,} 1 \mathrm{mM}$ DTT, and $50 \mathrm{ng} \mu \mathrm{L}^{-1}$ polydeoxyinosinicdeoxycytidylic acid (poly dI-dC). In each reaction, $\mathrm{MBP}-\mathrm{Mog} \mathrm{R}$ or $\mathrm{MBP}-\mathrm{Mog} \mathrm{R}^{\mathrm{QN} \rightarrow A A}$ was added to approximately 2 fmol biotinylated DNA probe and incubated for $20 \mathrm{~min}$ at room temperature. Each binding reaction was loaded on a $5 \%$ SDS-PAGE gel $(0.5 \times$ TBE $)$ and resolved for $1 \mathrm{~h}$ at $100 \mathrm{~V}$. Gels were blotted onto a nylon membrane and DNA was crosslinked to the membrane by exposure to UV light $\left(120 \mathrm{~mJ} / \mathrm{cm}^{2}\right)$ for $60 \mathrm{~s}$. Finally, biotin-labeled DNA was detected using chemiluminescense as described in the EMSA kit instructions.

\section{Quantification of Cyclic di-GMP by LC-MS/MS}

LC-MS/MS analysis was based on a method described by Spangler et al. (2010), with some modifications, as previously described (Fagerlund et al., 2016), using a Thermo Scientific LTQ XL Linear Ion Trap Mass Spectrometer (Thermo Scientific) and separation on a $5 \mathrm{~mm} \times 1 \mathrm{~mm}$ I.D. Nucleodur C18 Pyramid precolumn and a $50 \mathrm{~mm} \times 1 \mathrm{~mm}$ I.D. Nucleodur C18 pyramid analytical column (both from Marchery-Nagel), with an electrospray ionization (ESI) source operated in the positive ionization mode to interface the HPLC and the MS.

\section{Statistical Analyses}

Minitab v.17 software was used for statistical analysis. Unless stated otherwise, all data were analyzed using analysis of variance (ANOVA) followed by Tukey's post hoc test for pairwise comparisons. $P$-values $<0.05$ were regarded as significant.

\section{RESULTS}

\section{The Motility Gene Loci in B. thuringiensis and $L$. monocytogenes Are Closely Related}

A cluster of approximately 45-50 genes with homology to flagellar-based motility- and chemotaxis genes is present in most $B$. cereus group strains. Although $B$. cereus group bacteria are phylogenetically more closely related to $B$. subtilis than to $L$. monocytogenes, some aspects of organization of the $B$. thuringiensis 407 flagellar motility gene cluster were found to more closely resemble that of L. monocytogenes. Bidirectional BLAST analysis showed that a greater number of motility protein orthologs is shared between B. thuringiensis 407 and L. monocytogenes EGD-e (41 orthologous proteins, average alignment percentage identity 46\%) than between B. thuringiensis 407 and B. subtilis 168 (31 orthologous proteins, $37 \%$ average sequence identity) (Supplementary Table 1). Furthermore, only other Listeria spp. and species of the $B$. cereus group are known to have orthologs to the L. monocytogenes motility gene repressor MogR (Gründling et al., 2004; Smith and Hoover, 2009), potentially indicating that elements of motility regulation may be shared between these species (Figure 1 and Supplementary Table 1).

\section{Non-motile $B$. anthracis and B. pseudomycoides Have Retained mogR}

As has previously been noted (Klee et al., 2010), comparative alignments between the motility loci of different $B$. cereus group strains indicate that the flagellin gene locus is an evolutionary hotspot, as the number of flagellin genes in each strain varies between one and five copies, and several strains also contain additional sets of genes in this locus. Isolates belonging to the $B$. cereus group may be divided into seven phylogenetic subgroups (I to VII) and for which, with the exception of B. pseudomycoides (group I) and B. cytotoxicus (group VII), species designations do not strictly follow the phylogenetic group designations. Instead, isolates belonging to the different phylogenetic subgroups have distinct ecotypes and preferred growth temperature ranges (Guinebretière et al., 2008). An analysis of $B$. cereus group genomes revealed striking differences between the motility gene clusters in strains belonging to the various phylogenetic groups (Figure 2). The motility gene clusters of strains in phylogenetic subgroups III, IV and V were overall highly similar to that of $B$. thuringiensis 407 , with a few exceptions mainly related to insertion of transposable elements and variation in the number of flagellin genes. Of note, strains of $B$. anthracis, which constitutes a highly clonal lineage within subgroup III, all carry an $11.5 \mathrm{~kb}$ insertion in place of the second flagellin gene $(f l a B)$, as well as nonsense mutations in 


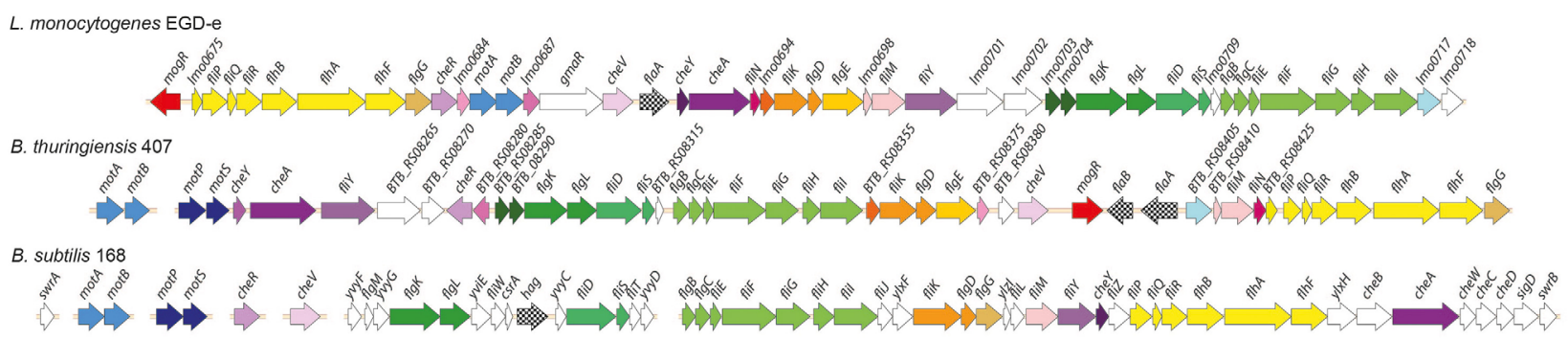

FIGURE 1 | Comparison of genomic loci encoding flagellar-based motility genes in Listeria monocytogenes, Bacillus thuringiensis and B. subtilis. Top: L. monocytogenes (Lm) EGD-e (single chromosomal locus). Middle: B. thuringiensis (Bt) 407 (two chromosomal loci). Bottom: B. subtilis (Bs) 168. The Bs 168 gene annotations are in accordance with gene or protein names for the corresponding RefSeq entries. Where orthologs to the Bs 168 genes are present in Bt 407 and/or Lm EGD-e, as determined by reciprocal best BLAST hits, these are given the same gene names, except for fliS, fliE, fliH, og hag/flaA/flaB (see Supplementary Table 1). Annotation for the following genes lacking Bs 168 orthologs is according to the specified references: mogR (Gründling et al., 2004), gmaR (Shen et al., 2006), flgE (NP_464224 and ZP_04138734), and fliN (ZP_04138744). Hypothetical genes in Lm EGD-e and Bt 407 are indicated by locus tags. Protein orthologs or blocks of colinear orthologs are indicated by identical coloring in two or three strains. Genes shown in white do not have orthologs in any of the two other strains.

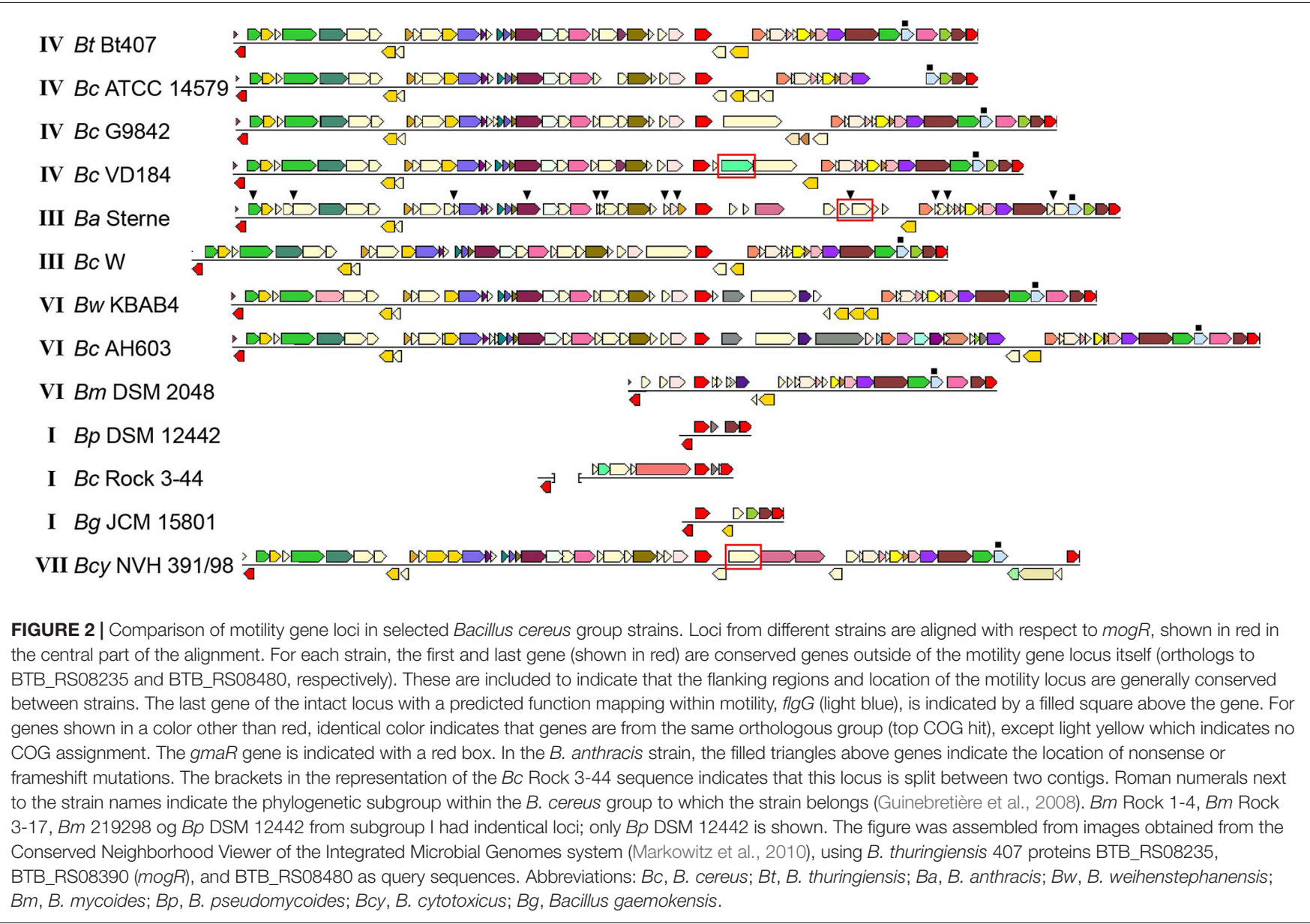

a series of the conserved motility genes (motP, cheA, flgL, fliF, BAS1560 [ortholog to BTB_RS08355], fliK, BAS1570 [ortholog to BTB_RS08380], cheV, BAS1584 [ortholog to BTB_RS08410], $f l i M$, and $f l h F)$. B. anthracis strains are thus non-motile, however still carry an intact $\operatorname{mog} R$ gene (Figure 2).

Phylogenetic subgroup I corresponds to the species B. pseudomycoides, but also includes strains for which an original identification as B. cereus or B. mycoides has not yet been revised (Guinebretière et al., 2008). BLASTP searches were performed against available subgroup I proteomes using the corresponding protein sequences for the genes from the motility locus of $B$. thuringiensis 407 as query (Figure 2). Among six fully sequenced strains (single scaffold per replicon or closed genome) belonging to subgroup I (219298, BTZ, 
Rock 3-44, DSM 12442, Rock 1-4 and Rock 3-17), all contained a severely reduced motility gene cluster, and strikingly, the only conserved motility-related gene in the motility locus of these strains is $\operatorname{mog} R$ (Figure 2). The absence of all motility genes except $\operatorname{mog} R$ in all six fully sequenced group I strains analyzed, as well as in all except for one (AFS092012) of the 100 additional group I strains annotated as B. pseudomycoides at the NCBI and for which a genome sequence at scaffold level was available, indicates that absence of motility is likely a general characteristic of this genetic group, in line with the description of B. pseudomycoides as a non-motile species (Nakamura, 1998). The predicted MogR proteins of the B. pseudomycoides group show $\sim 56 \%$ and $\sim 30 \%$ pairwise identity to the corresponding orthologs in B. thuringiensis 407 and L. monocytogenes EGD-e, respectively. A multiple sequence alignment demonstrated that the L. monocytogenes MogR residues predicted to make base-specific DNA contacts in L. monocytogenes (Shen et al., 2009) have been conserved in the MogR proteins from all examined B. cereus group strains, including those belonging to non-motile species (Supplementary Figure 1). Interestingly, an ortholog of gmaR, encoding a temperature-controlled antirepressor of MogR in L. monocytogenes (Kamp and Higgins, 2009), is found in B. cytotoxicus strains (cluster VII), but is absent in most $B$. cereus group strains belonging to other phylogenetic clusters.

\section{Flagellin Gene Expression Drops Following a Sharp Increase in $\operatorname{mog} R$ Expression}

B. thuringiensis 407 produces two flagellins, structural proteins building the flagellum main filament, from chromosomal genes flaA and flaB (Lövgren et al., 1993). Expression of $m o g R$ (BTB_RS08390), flaA (BTB_RS08400) and flaB (BTB_RS08395) was followed at the transcriptional level throughout the bacterial growth phase using RT-qPCR. In contrast to previous proteomics studies which indicated that in $B$. thuringiensis 407 only the first flagellin gene $(f l a A)$ was expressed in early stationary phase (Gohar et al., 2005), results showed that both flaA and $f l a B$ are indeed expressed at the RNA level, although expression of flaA was approximately four-fold higher than that of flaB (Figure 3). The two fla genes reached maximum expression at $3.5 \mathrm{~h}$, at the transition between exponential and stationary growth phase, in agreement with corresponding data obtained using a transcriptional fusion between lac $Z$ and the flaA promoter (Houry et al., 2010). These data also corresponded well with microscopic observations of cultures sampled throughout the growth phase. The expression of $\operatorname{mog} R$ increased 64-fold between the $2.5 \mathrm{~h}$ and $3.5 \mathrm{~h}$ time-point (Figure 3), peaking at $4 \mathrm{~h}$, at which time flaA and $f l a B$ expression was rapidly decreasing. This is in parallel with the expression pattern found for $\operatorname{mog} R$ in B. anthracis (Bergman et al., 2006). While downregulation of motility-related genes upon entry to the stationary phase is common in both Gramnegative and Gram-positive bacteria (Ramírez Santos et al., 2005; Han et al., 2017), it was nevertheless interesting to note that expression of the $f l a A$ and $f l a B$ genes dropped after

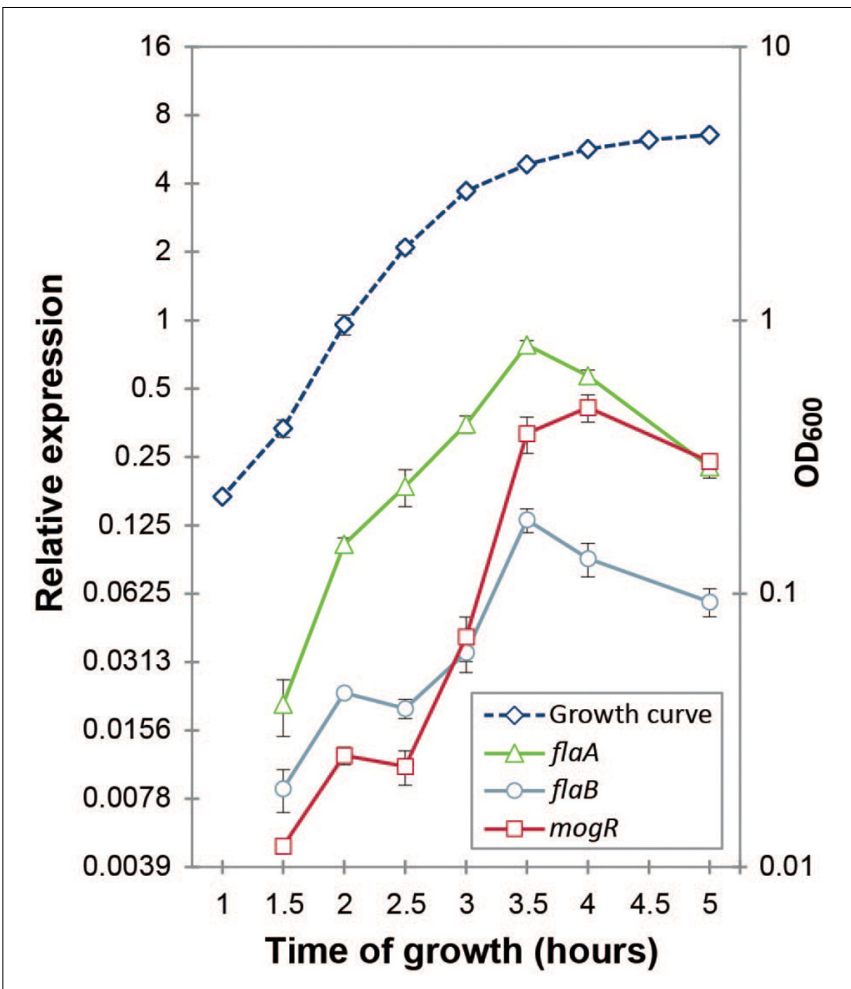

FIGURE 3 | Gene expression analysis of $\operatorname{mog} R$ and flagellin genes fla $A$ and flaB by RT-qPCR. The expression of each gene at each time-point was normalized to the expression of the reference genes gat $B, r p s U$ and $u d p$. Cultures were grown at $30^{\circ} \mathrm{C}$ in bactopeptone culture medium, with the growth curve plotted on the right-hand vertical axis. Averages and standard errors of the means from three independent experiments are shown.

$3.5 \mathrm{~h}$, subsequent to the sharp increase in $\operatorname{mog} R$ transcription (Figure 3), in line with a role for MogR in repression of motility in B. thuringiensis.

\section{Overexpression of MogR Renders $B$. thuringiensis 407 Non-flagellated and Non-motile}

A MogR overexpression strain was constructed using the pHT304- $\mathrm{P}_{x y l}$ expression vector carrying a xylose-inducible promoter, as well as an isogenic strain overexpressing a version of MogR where two mutations were introduced: Q119A and N120A (plasmids and strains used are listed in Table 1). In the mutated protein (referred to as $\operatorname{Mog} \mathrm{R}^{Q N \rightarrow A A}$ ), alanine substitutions were made for two of the six amino acids corresponding to residues in L. monocytogenes MogR that were shown to make base-specific contacts with DNA, in cognate DNA recognition sites positioned upstream of $L$. monocytogenes genes that were subject to direct MogR transcriptional repression (Shen et al., 2009; Supplementary Figure 1). Cellular growth rates were not affected by MogR or MogR $\mathrm{R}^{\mathrm{M}} \rightarrow A A$ overexpression (relative to an empty vector control) at $25^{\circ} \mathrm{C}, 30^{\circ} \mathrm{C}$ or $37^{\circ} \mathrm{C}$ (Supplementary Figure 2). 
TABLE 1 | Strains and plasmids used in this study.

\begin{tabular}{|c|c|c|}
\hline Strain or plasmid & Description & Reference or source \\
\hline \multicolumn{3}{|l|}{ PLASMIDS } \\
\hline pHT304- $\mathrm{P}_{x y l}$ & Low copy number expression/shuttle vector; xylA promoter $\left(\mathrm{Ap}^{r}, \mathrm{Ery}^{r}\right)$ & (Arantes and Lereclus, 1991; Salamitou et al., 1997) \\
\hline $\mathrm{pHT} 304-\mathrm{P}_{x y l}-\operatorname{mog} R$ & wild type mogR in pHT304- $\mathrm{P}_{x y l}$ & This study \\
\hline $\mathrm{pHT304-P_{xyl } - m o g R ^ { Q N } \rightarrow A A}$ & Q119A, N120A mutant mogR in pHT304-P $\mathrm{P}_{x y l}$ & This study \\
\hline pMAL-p5X & Expression vector for production of MBP fusions, IPTG promoter $\left(\mathrm{Ap}^{r}\right)$ & New England Biolabs \\
\hline pMAL-p5X-mogR & wild type $m o g R$ in pMAL-p5X & This study \\
\hline pMAL-p5X-mogR $R^{Q N} \rightarrow A A$ & Q119A, N120A mutant mogR in pMAL-p5X & This study \\
\hline \multicolumn{3}{|l|}{ STRAINS } \\
\hline \multicolumn{3}{|l|}{ B. thuringiensis } \\
\hline 407 & B. thuringiensis 407 Cry $^{-}$ & (Lereclus et al., 1989) \\
\hline 407/pHT304- $P_{x y l}$ & pHT304- $P_{x y l}$ in 407 & This study \\
\hline 407/MogR $\mathrm{R}^{+}$ & pHT304- $P_{x y l}-m o g R$ in 407 & This study \\
\hline $407 / \mathrm{Mog}^{Q N} \rightarrow A A$ & $\mathrm{pHT304-P_{xyl } - m o g R ^ { Q N } \rightarrow A A}$ in 407 & This study \\
\hline $407 \Delta f l a A B$ & B. thuringiensis $407 \Delta$ flaA $\Delta$ flaB $\left(\mathrm{Km}^{r}\right)$ & (Houry et al., 2010) \\
\hline $407 \Delta$ flaAB/pHT304-P $x y l$ & pHT304-P $P_{x y l}$ in $407 \Delta f l a A B$ & This study \\
\hline $407 \Delta$ flaAB/MogR ${ }^{+}$ & pHT304- $\mathrm{P}_{x y l}-m o g R$ in $407 \Delta$ flaAB & This study \\
\hline $407 \Delta f l a A B / \operatorname{Mog}^{Q N} \rightarrow A A$ & $\mathrm{pHT304-P_{xyl } - m o g R ^ { Q N } \rightarrow A A}$ in $407 \Delta$ flaAB & This study \\
\hline \multicolumn{3}{|l|}{ E. coli } \\
\hline BL21(DE3) & E. coli BL21(DE3) & New England Biolabs \\
\hline $\mathrm{BL} 21 / \mathrm{MogR}^{+}$ & pMAL-p5X-mogR in BL21(DE3) & This study \\
\hline $\mathrm{BL} 21 / \mathrm{Mog}^{Q N} \rightarrow A A$ & pMAL-p5X-mogR $R^{Q N} \rightarrow A A$ in BL21(DE3) & This study \\
\hline
\end{tabular}

Motility of the MogR overexpression strain was investigated by swimming assays employing $0.3 \%$ LB agar plates, showing that cells overexpressing MogR were non-motile, and that the repression of motility was dependent on the two amino acid residues (Q119 and $\mathrm{N} 120)$ mutated in $\operatorname{Mog} \mathrm{R}^{Q N} \rightarrow A A$, at $30^{\circ} \mathrm{C}$ (Figures $4 \mathbf{A}, \mathbf{B}$ ), as well as at $25^{\circ} \mathrm{C}$ and $37^{\circ} \mathrm{C}$. Swimming motility was also monitored by light microscopy and found to be completely lost upon MogR overexpression at all time points and temperatures examined (every half hour between 1 and $7 \mathrm{~h}$ of cultivation, at $25^{\circ} \mathrm{C}, 30^{\circ} \mathrm{C}$ and $37^{\circ} \mathrm{C}$ ). To determine whether the reduced motility was due to a loss of flagellar structure or flagellar rotation, strains were analyzed by Atomic Force Microscopy (AFM). AFM analyses showed that the $\operatorname{Mog} \mathrm{R}$ overexpression strain was completely devoid of flagellar structures, while overexpression of $\operatorname{MogR}^{Q N} \rightarrow A A$ restored the empty vector control phenotype (Figures $4 \mathrm{D}-\mathrm{F}$ ). In accordance, a Western blot of the MogR overexpression strain using anti-flagellin antibodies showed that flagellin proteins were below the level of detection in whole cell extracts and severely attenuated in outer cell surface extracts compared to in the vector control strain, while being expressed at comparable levels in the B. thuringiensis 407 wild type strain and in B. thuringiensis 407 overexpressing $\operatorname{Mog} \mathrm{R}^{Q N \rightarrow A A}$ (Figure 4G). In a flaAB negative control strain in which the genes encoding the FlaA and FlaB flagellins had been deleted, no flagellin proteins could be detected neither in the whole cell extract nor on the cell surface. In L. monocytogenes, flagellin genes were previously found to be directly repressed by $\operatorname{Mog} R$, and in order to investigate if MogR function was conserved in B. thuringiensis 407, the expression of flagellin genes was investigated in the MogR overexpression strain relative to the empty vector and $\operatorname{Mog} \mathrm{R}^{Q N} \rightarrow A A$ control strains, by quantitative RT-PCR. A 30-fold (flaA) and 50-fold $(f l a B)$ reduction in transcription, respectively, was seen in the MogR overexpression strain relative to the empty vector control, while no difference was observed relative to the empty vector strain when overexpressing $\operatorname{Mog} \mathrm{R}^{Q N \rightarrow A A}$ (Figure 4C).

\section{Overexpression of MogR Affects the Expression of Genes Not Related to Motility Functions}

Global microarray-based transcriptional profiling was used to identify genes whose expression was affected by MogR overexpression in $B$. thuringiensis 407 relative to the empty vector control strain. Samples were taken in the early stationary growth phase $(3 \mathrm{~h})$, and a total of 110 genes were identified to be differentially regulated by MogR (FDR-corrected $p<0.05$ ), either directly or indirectly. Selected genes are listed in Table 2 (see Supplementary Table 3 for complete list). Of the differentially expressed genes, 87 were repressed by $\operatorname{Mog} \mathrm{R}$ overexpression, while 23 genes exhibited higher transcriptional levels compared to the control. In total, 21 motility genes were downregulated by MogR overexpression, including flagellin genes fla $\mathrm{A}$ and $\mathrm{flaB}$ (Supplementary Figure 3). Overexpression of MogR affected genes widely dispersed in the motility loci, including the $\operatorname{mot} A B$ operon located separately in the chromosome. Interestingly, the microarray analysis revealed that $\operatorname{Mog} \mathrm{R}$ also affected the expression of 89 nonmotility-related genes, including six virulence genes which were downregulated. The latter genes included inhA encoding immune inhibitor $\mathrm{A}, h b l A$ and $h b l D$ encoding enterotoxin binding component B and lytic component L1, respectively, sfp 


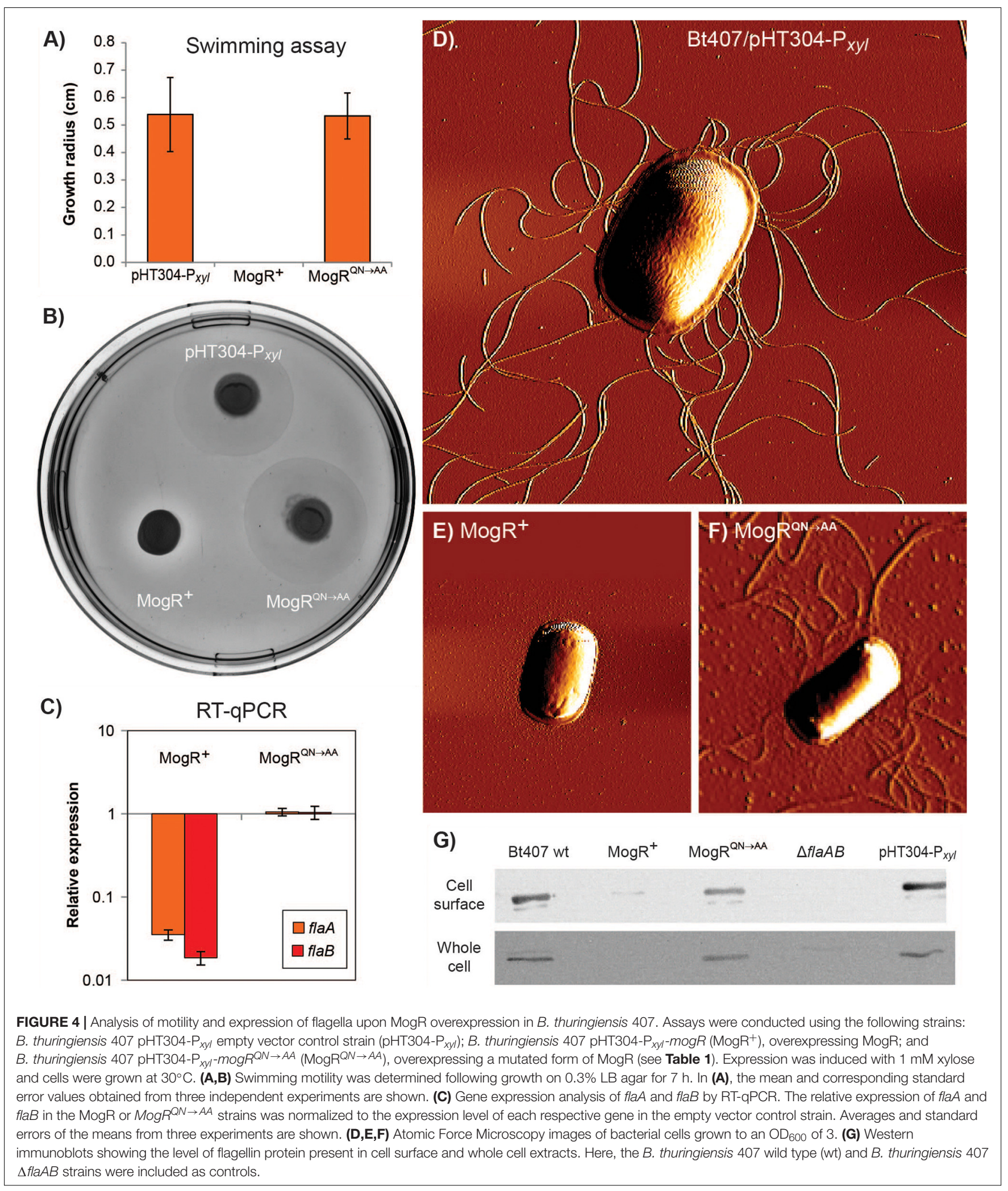

encoding a subtilase family serine protease, as well as genes encoding phosphatidyl-choline specific phospholipase $\mathrm{C}$ and sphingomyelinase. Also downregulated were five stress-related genes: the groES, groEL and $\operatorname{grpE}$ chaperonin genes, sigB encoding the $\sigma^{B}$ alternative sigma factor, and $h r c A$. The gene encoding the pleiotropic transcriptional regulator NprR 
TABLE 2 | Genome-wide gene expression analysis of B. thuringiensis 407 overexpressing MogR relative to an empty vector control strain using oligonucleotide microarrays.

\begin{tabular}{|c|c|c|c|c|}
\hline Gene & $\begin{array}{l}\text { Locus tag in } \\
\text { B. thuringiensis } 407\end{array}$ & $\begin{array}{l}\text { Locus tag in } \\
\text { B. cereus ATCC } \\
14579\end{array}$ & Predicted function & $\begin{array}{l}\log _{2} \text { (fold change) in } \\
\text { MogR } \\
\text { overexpression strain } \\
\text { relative to control }\end{array}$ \\
\hline \multicolumn{5}{|c|}{ Motility-related gene function } \\
\hline cheA & BTB_RS08255 & $\mathrm{BC} 1628$ & Chemotaxis protein, histidine kinase CheA & -1.80 \\
\hline flgK & BTB_RS08295 & $\mathrm{BC} 1636$ & Flagellar hook-associated protein 1, FlgK & -1.67 \\
\hline flis & BTB_RS08310 & BC1639 & Flagellar biosynthesis protein FliS & -0.68 \\
\hline flgC & BTB_RS08325 & BC1642 & Flagellar basal-body rod protein FlgC & -2.87 \\
\hline fliF & BTB_RS08335 & BC1644 & Flagellar M-ring protein FliF & -2.31 \\
\hline fliG & BTB_RS08340 & BC1645 & Flagellar motor switch protein FliG & -1.09 \\
\hline flik & BTB_RS08355 & BC1649 & Flagellar hook-length control protein FliK & -1.47 \\
\hline cheV & BTB_RS08385 & BC1654 & Chemotaxis signal transduction protein CheV & -1.80 \\
\hline flaB & BTB_RS08395 & BC1656 & Flagellin FlaB & -1.04 \\
\hline flaA & BTB_RS08400 & $\mathrm{BC} 1657$ & Flagellin FlaA & -3.45 \\
\hline fliN & BTB_RS08425 & $\mathrm{BC} 1661$ & Flagellar motor switch protein (fliN-homolog) & -0.99 \\
\hline fliP & BTB_RS08430 & BC1665 & Flagellar biosynthesis protein FliP & -1.86 \\
\hline fliQ & BTB_RS08435 & $\mathrm{BC} 1666$ & Flagellar export apparatus protein FliQ & -1.23 \\
\hline fliR & BTB_RS08440 & $\mathrm{BC} 1667$ & Flagellar biosynthesis protein FliR & -1.02 \\
\hline$f / h B$ & BTB_RS08445 & BC1668 & Flagellar biosynthesis protein FlhB & -1.60 \\
\hline flhA & BTB_RS08450 & BC1669 & Flagellar biosynthesis protein FlhA & -1.43 \\
\hline motB & BTB_RS22905 & BC4512 & Flagellar motor protein MotB $\left(\mathrm{H}^{+}\right.$-coupled stator $)$ & -3.01 \\
\hline $\operatorname{mot} A$ & BTB_RS22910 & BC4513 & Flagellar motor protein MotA $\left(\mathrm{H}^{+}\right.$-coupled stator $)$ & -1.74 \\
\hline$m c p A$ & BTB_RS02175 & BC0422 & Methyl-accepting chemotaxis protein (carrying upstream "off" c-di-GMP riboswitch) & -1.31 \\
\hline \multicolumn{5}{|c|}{ Virulence-related gene function } \\
\hline$n p r R$ & BTB_RS03040 & BC0598 & Transcriptional activator NprR (necrotrophism regulator & -0.89 \\
\hline $\operatorname{inh} A$ & BTB_RS03410 & BC0666 & Immune inhibitor A & -1.03 \\
\hline plcB & BTB_RS03430 & BC0670 & Phospholipase C (PC-PLC) & -2.32 \\
\hline sph & BTB_RS03435 & BC0671 & Sphingomyelinase C (Smase) & -1.47 \\
\hline$h b / A$ & BTB_RS12545 & BC3102 & Hbl component B & -1.13 \\
\hline$h b / D$ & BTB_RS12540 & BC3103 & Hbl component L1 & -1.59 \\
\hline$s f p$ & BTB_RS18825 & BC3762 & Serine protease (subtilase family) & -0.84 \\
\hline$c b p A$ & BTB_RS05575 & $\mathrm{BC} 1060$ & Collagen adhesion protein (carrying upstream c-di-GMP "on" riboswitch) & 3.02 \\
\hline \multicolumn{5}{|c|}{ Putative biofilm-related gene function } \\
\hline $\sin 1$ & BTB_RS06545 & $\mathrm{BC} 1283$ & Sinl biofilm repressor antagonist & 1.08 \\
\hline$y w g C$ & BTB_RS26935 & BC5278 & Putative capsular polysaccharide biosynthesis protein & 0.71 \\
\hline
\end{tabular}

(Dubois et al., 2012) was also downregulated. Among the 23 genes upregulated in the MogR overexpression strain were $\sin I$, encoding a protein inducing biofilm formation by direct interaction and sequestration of the biofilm repressor SinR, and a putative capsular polysaccharide biosynthesis protein-encoding gene (BTB_RS26935) corresponding to BC5278 in B. cereus strain ATCC 14579. The genes BC5267 to BC5278 constitute a conserved locus in $B$. cereus and $B$. thuringiensis and are homologous to the epsAO locus of $B$. subtilis involved in the synthesis of the exopolysaccharide component of the biofilm matrix (Branda et al., 2001; Ivanova et al., 2003; Kearns et al., 2005; Fagerlund et al., 2014). Genes in this locus have been found to be implicated in biofilm formation in $B$. cereus in a pellicle biofilm model (Hayrapetyan et al., 2015; Okshevsky et al., 2017). Another upregulated gene was $c b p A$, encoding a collagen adhesion protein positively regulated by c-di-GMP (Finke et al., 2019).

\section{Q119 and N120 Are Critical for MogR Binding to Specific Sites in the $B$. thuringiensis 407 Genome in vitro}

DNA regions upstream of genes differentially expressed in the B. thuringiensis $407 \mathrm{MogR}$ overexpression strain were investigated for candidate MogR binding sites, based on sequence searches using the L. monocytogenes consensus MogR binding sequence (TTTTWWNWWAAAA; Shen et al., 2009). Three putative binding sites were predicted in the intergenic region upstream of the flagellin (flaAB) operon, two potential sites upstream of cheY, while four putative binding sites were predicted in the promoter region of the $h b l$ operon (Lindbäck et al., 1999), all overlapping the -10 promoter element (Figure 5A). Among the other genes downregulated by MogR overexpression, multiple binding sites were found upstream of inhA, as 


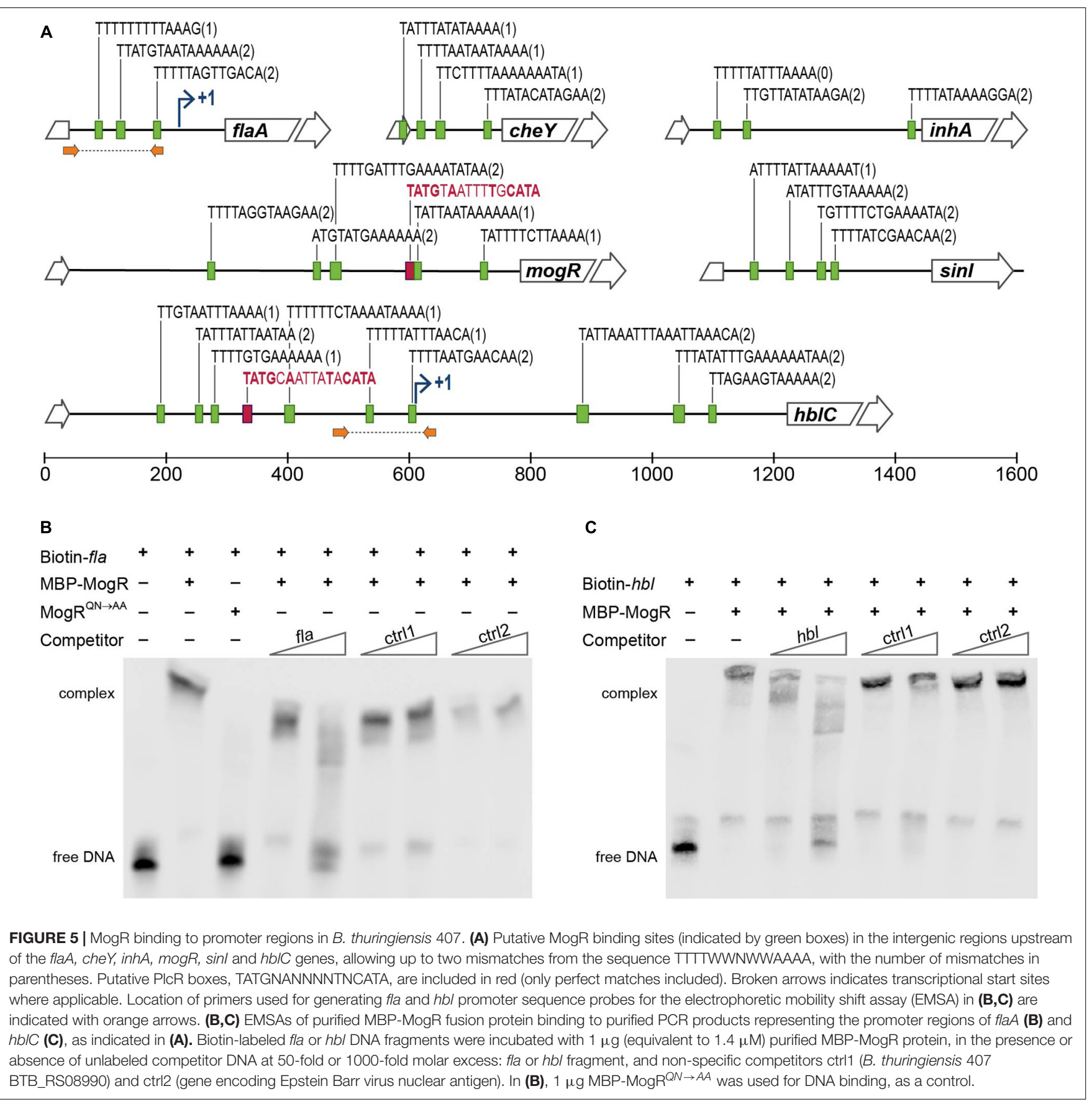

well as upstream of the biofilm-promoting gene sinI and $\operatorname{mog} R$ itself.

To determine whether $B$. thuringiensis MogR can function as a DNA-binding protein, and investigate whether MogR may affect the expression of candidate genes in B. thuringiensis 407 by directly binding to upstream regulatory regions, we carried out electrophoretic mobility shift assays (EMSA) with a purified maltose-binding protein (MBP)-MogR fusion protein, and purified DNA fragments constituting PCR-amplified candidate regulatory regions (Figure 5A). Two promoter regions upstream of genes shown to be differentially expressed in the microarray experiments were selected for analysis. Results showed that MogR could bind the promoter regions upstream of both $f l a A B$ and the $h b l$ enterotoxin locus in vitro (Figures $5 \mathbf{B}, \mathbf{C}$ ). The amount of MogR protein to be used in the assay had been optimized by titration in a prior experiment (Supplementary Figure S4). Importantly, DNA binding was abolished when the experiment was performed using $\operatorname{Mog} \mathrm{R}^{\mathrm{QN}} \rightarrow A A$, in which the conserved Q119 and N120 residues shown to make base-specific contacts with the MogR recognition site in L. monocytogenes (Shen et al., 2009) had been substituted (Figure 5B). The binding reactions to which competing unlabeled DNA were added (labeled ctrl1 and ctrl2 
in Figures 5B,C) indicated that MogR exhibits sequence specific binding to $f l a A B$ and $h b l$ upstream regions in vitro.

\section{Cytotoxin Production and Virulence Are Reduced Upon MogR Overexpression}

Western blot analyses were performed to measure the effect of MogR overexpression on the amount of secreted enterotoxins. The genes encoding the $\mathrm{Hbl}, \mathrm{CytK}$ and Nhe enterotoxins are all part of the PlcR regulon (Gohar et al., 2008), and thus commonly co-regulated in B. cereus group bacteria. Therefore, the expression of all three was examined, despite the fact that an upstream promoter containing putative MogR binding sites and differential expression upon MogR overexpression was only observed for the genes encoding Hbl. All three enterotoxins were present but at clearly reduced levels in the culture supernatant from the MogR overexpression strain, compared to that of empty vector and $\operatorname{Mog} \mathrm{R}^{\mathrm{QN} \rightarrow A A}$ control strains (Figure 6A). To further assess the effect of MogR on virulence capacity, supernatants collected from mutant and overexpression strains grown to exponential phase were tested in an in vitro Vero cell toxicity assay (Lindbäck and Granum, 2006). Supernatants from the MogR overexpressing strain, which synthesized lower amounts of the $\mathrm{Hbl}$, Nhe and CytK toxins (Figure 6A), were less cytotoxic than those of the empty vector control $(p=0,059)$ and the $\operatorname{Mog}^{Q N \rightarrow A A}$ strain (Figure 6B). In order to more confidently assess the effect of MogR on virulence, an in vivo model was used, where the strains were tested in an oral infection model using Galleria mellonella larvae. In accordance with the in vitro toxicity data, the MogR overexpressing strain was severely attenuated in virulence compared to the empty vector control strain in vivo $(p=0.02$; Figure 6C).

\section{Biofilm Formation Is Increased Upon MogR Overexpression in a flaAB Negative Background}

The $\operatorname{Mog} R$ overexpression strain was compared to the empty vector and $\mathrm{MogR}^{\mathrm{QN} \rightarrow A A}$ strains both in glass tube and microtiter plate biofilm assays (Figures $\mathbf{7 A , B}$ ). The glass tube assay showed similar development of a biofilm pellicle at the airliquid surface in all three strains: After $72 \mathrm{~h}$ the pellicle in the MogR overexpression strain was only slightly (14\%) thicker than that of the empty vector and $\mathrm{MogR}^{Q N \rightarrow A A}$ strains (Figure 7A). In the microtiter plate assay, no significant effect of MogR overexpression on biofilm formation was observed at 48 or $72 \mathrm{~h}$, with a slight decrease in biofilm formation at $24 \mathrm{~h}$ compared to $\operatorname{Mog} \mathrm{R}^{\mathrm{QN} \rightarrow A A}$ and empty vector controls (Figure 7B). Overexpression in a $\triangle$ flaAB background however allowed examination of the effect of the MogR protein on biofilm formation, independently of any effect conferred through flagella. Interestingly, in the $\triangle f l a A B$ host, overexpression of MogR led to a substantial increase in biofilm formation relative to the $\operatorname{Mog} \mathrm{R}^{\mathrm{QN} \rightarrow A A}$ and empty vector controls (Figure 7C), while biofilm formation in the control strain overexpressing $\operatorname{MogR} R^{Q N \rightarrow A A}$ was comparable to that of the strain carrying empty vector. Intriguingly, LC-MS/MS quantitation of the biofilm-related second messenger cyclic di-GMP (c-di-GMP) in cellular extracts indicated slightly increased levels of c-diGMP in the MogR overexpression strain (wild type background; three measurements: $8.38 \mathrm{ng} \mathrm{mL}-1 ; 6.0 \mathrm{ng} \mathrm{mL}-1 ; 9.0 \mathrm{ng}$ $\mathrm{mL}^{-1}$ ) compared to the $B$. thuringiensis 407 empty vector strain (two measurements: < LOD; $6.0 \mathrm{ng} \mathrm{mL}^{-1}$ ) (Limit of detection, LOD: $0.8 \mathrm{ng} \mathrm{mL}^{-1}$; Limit of quantitation, LOQ: $3.5 \mathrm{ng}$ $\mathrm{mL}^{-1}$ ).

\section{DISCUSSION}

Overexpression of MogR leads to repression of a range of motility genes in B. thuringiensis 407 , including the flagellins, rendering the bacteria non-flagellated and non-motile. In addition, amino acids in $B$. thuringensis MogR which correspond to those shown to mediate base-specific DNA contacts in L. monocytogenes $\operatorname{Mog} \mathrm{R}$ are clearly essential for $B$. thuringiensis MogR DNA binding in vitro. In accordance, overexpression of the mutated variant of $\operatorname{Mog} \mathrm{R}$ restores phenotypes to those of a vector control strain. Collectively these results, and analyses of MogR binding to predicted regulatory sites in vitro, strongly support the role of $B$. thuringiensis MogR as a DNA-binding transcriptional regulator and that the role of $\mathrm{MogR}$ as a key motility regulator in B. thuringiensis is conserved with that in L. monocytogenes. Global gene expression profiling however showed that in B. thuringiensis a large number of non-motility genes were also affected by MogR overexpression, including genes involved in stress response, virulence and biofilm formation. This was paralleled by an observed decrease in cytotoxin production, Vero cell toxicity and virulence in the G. mellonella infection model, indicating that MogR can affect additional phenotypes in B. cereus group bacteria. This is in apparent contrast to L. monocytogenes, where the primary function of $\operatorname{Mog} \mathrm{R}$ during intracellular infection is to repress flagellar motility gene expression, and where deletion of the flagellin gene $(f l a A)$ in a $\operatorname{mog} R$ deletion strain (producing $\triangle m o g R \triangle$ flaA) restores the $\mathrm{LD}_{50}$ values to wild type levels in a mouse model of infection (Shen and Higgins, 2006).

In bacteria, motility and virulence can be subject to coordinated downregulation, e.g., as is observed for intracellular signaling networks involving the second messenger c-di-GMP (Fagerlund et al., 2016). Flagellar motility and virulence appears to be co-regulated in B. cereus group bacteria (Zhang et al., 1993; Ghelardi et al., 2002; Bouillaut et al., 2005; Ghelardi et al., 2007a; Fagerlund et al., 2010; Salvetti et al., 2011; Mazzantini et al., 2016). For instance, a $B$. cereus strain deleted in $f l h A$, which encodes a component of the flagellum-formation apparatus, is impaired in adhesion (Ramarao and Lereclus, 2006), expression of virulence factors (Ghelardi et al., 2002; Fagerlund et al., 2010), and in cytotoxicity and virulence independently of PlcR (Bouillaut et al., 2005), which is the principal transcriptional activator of $B$. cereus virulence gene expression. Similarly, deletion of the gene encoding the signal recognition particle-like GTPase FlhF, located directly downstream of $f h A$, resulted in a marked reduction in the number of flagella, and a reduction in secretion 


\section{A Western immunoblots}

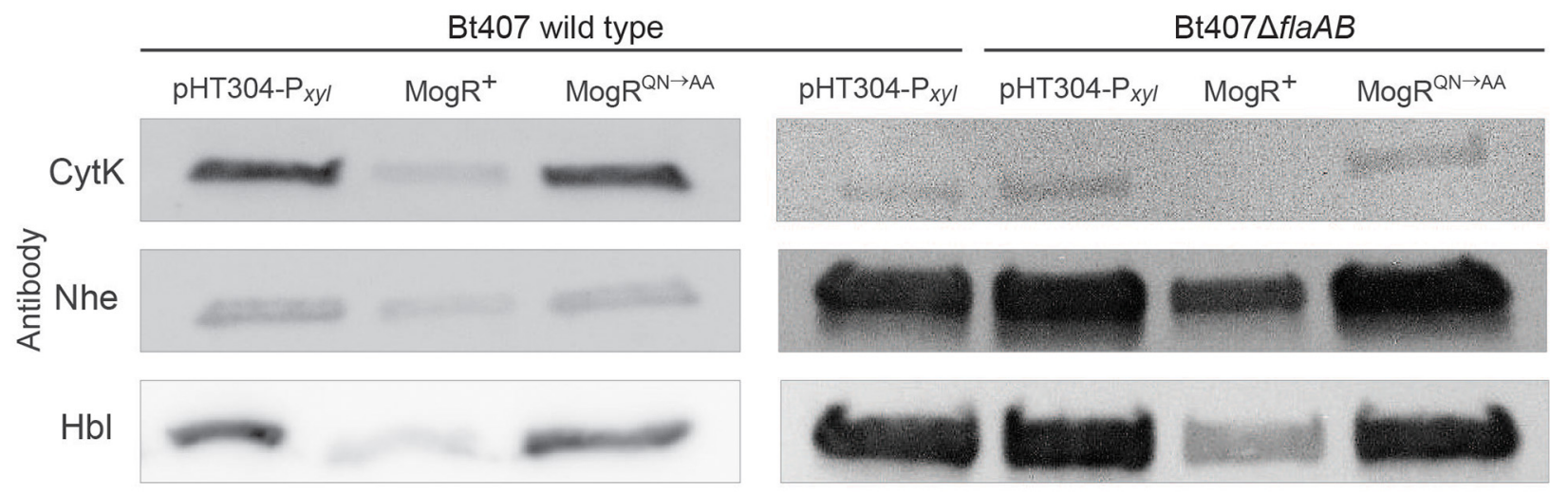

\section{B Vero cell cytotoxicity assay}

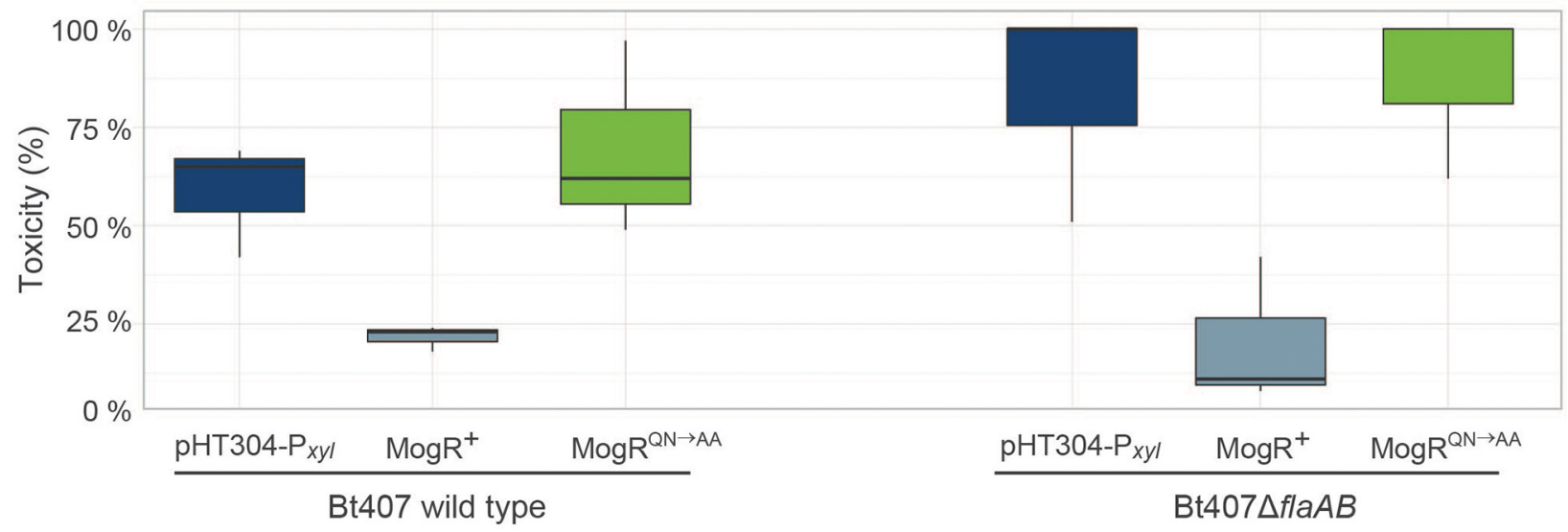

C Virulence in Galleria mellonella

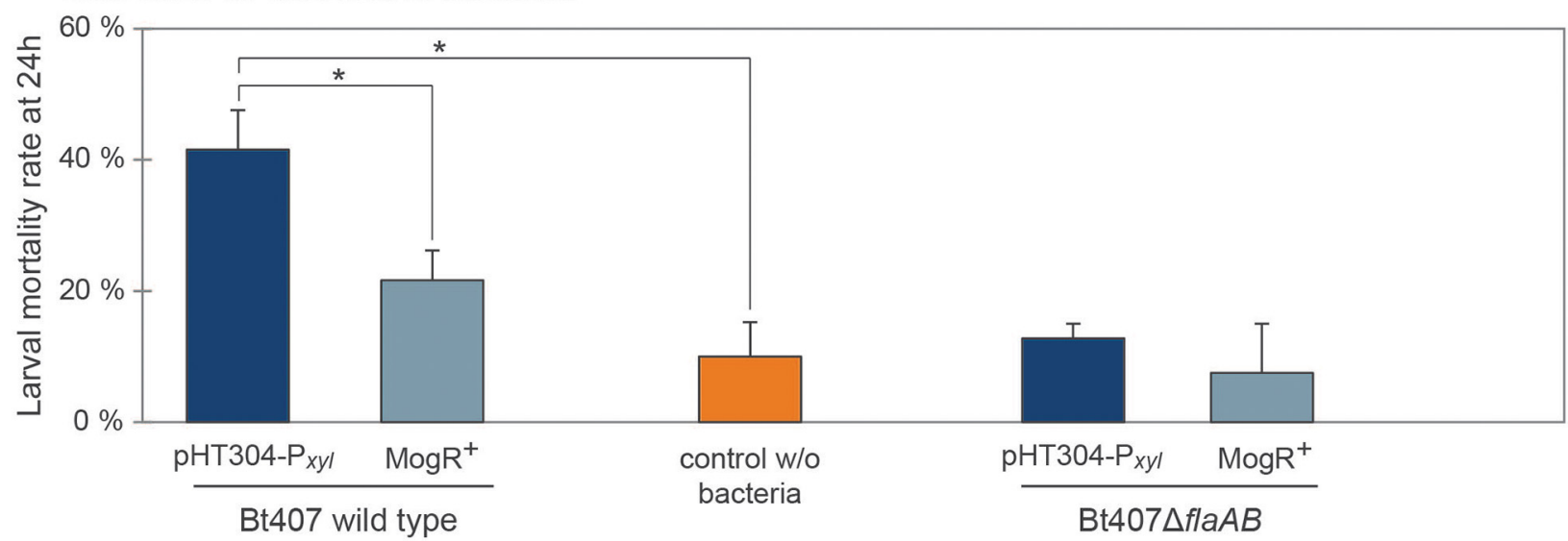

FIGURE 6 | Analysis of the effect of overexpression of MogR on virulence and toxicity phenotypes. (A) Immunoblots against CytK, Nhe and Hbl enterotoxins using culture supernatants from $B$. thuringiensis 407 carrying the empty vector (pHT304- $\mathrm{P}_{x y l}$ ), a MogR overexpression strain (MogR ${ }^{+}$), and a strain overexpressing a mutated form of MogR (MogR $\left.{ }^{Q N} \rightarrow A A\right)$. Constructs were analyzed in $B$. thuringiensis 407 wild type and flaAB deletion $(\triangle f l a A B)$ backgrounds. Cultures were grown for $4.5 \mathrm{~h}$ with $1 \mathrm{mM}$ xylose induction prior to harvest. The experiments were repeated at least three times and representative blots are shown. (B) Vero cell cytotoxicity assay using supernatants from cultures of the same strains as in (A). The median and first and third quartiles (25th percentile and 75th percentile) of three independent experiments are shown, as well as whiskers indicating the data variability outside the upper and lower quartiles. (C) Virulence in Galleria mellonella insect larvae (oral force-feeding infection model), using empty vector and MogR overexpression strains, in B. thuringiensis 407 wild type and $\triangle$ flaAB backgrounds, respectively. Bacteria were in all cases mixed with Cry $1 \mathrm{C}$ toxin and xylose. Also, a control with no bacteria but fed with Cry toxin and xylose was included. The means and standard errors of the mean (bars) of seven independent experiments are shown. Statistically significant differences (Tukey's post hoc test, $p<0.02)$ are indicated with asterisks $\left(^{\star}\right)$. 

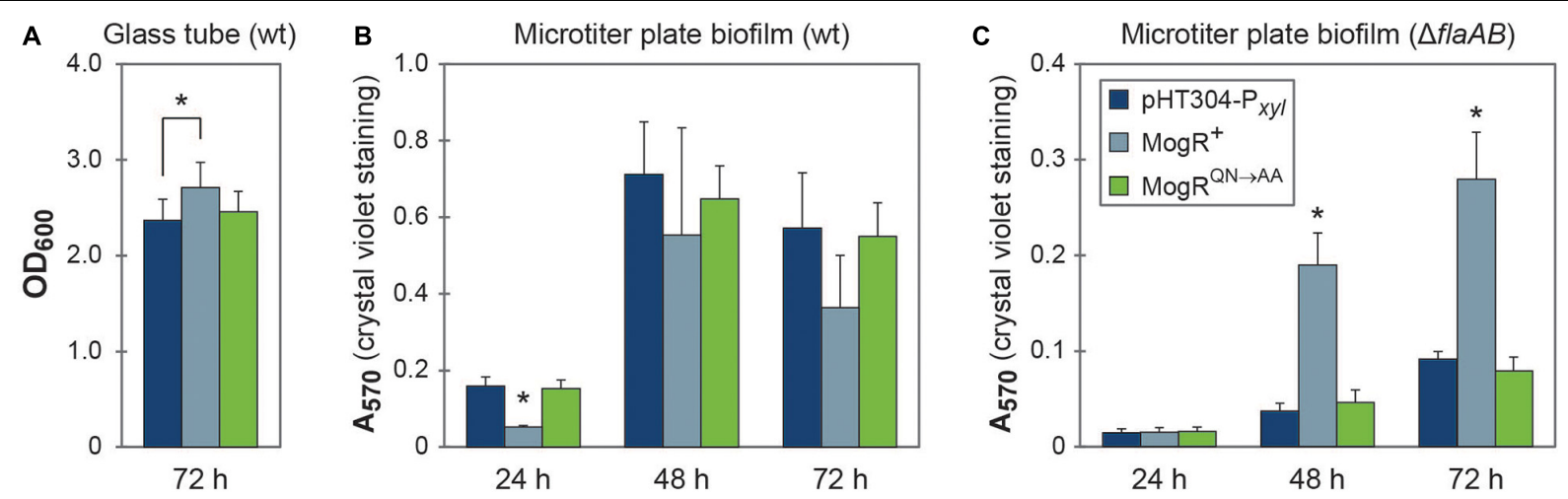

FIGURE 7 | MogR overexpression affects biofilm formation. (A) Biofilm formation in glass tubes after $72 \mathrm{~h}$ of growth. (B,C) Biofilm formation in a crystal violet microtiter plate assay after 24, 48, and $72 \mathrm{~h}$ of growth. The legend shown in (C) also applies to figures (A,B). The means and standard error of the means for $\mathbf{( A )}$ five or $(\mathbf{B}, \mathbf{C})$ three independent experiments is shown. Statistically significant differences (within each time point; Tukey's post hoc test, $p<0.05)$ are indicated with an asterisk $\left(^{*}\right)$; in $(\mathbf{B}, \mathbf{C})$ the asterisk $\left(^{*}\right)$ indicates that the $\mathrm{MogR}^{+}$strain demonstrates a statistically significant difference to both the empty vector control strain and the

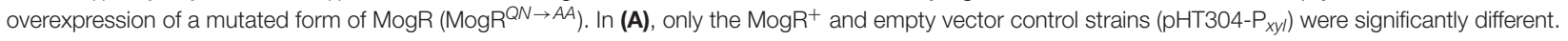

of several virulence-related proteins with attenuation of virulence (Salvetti et al., 2007; Mazzantini et al., 2016, 2020). A link between synthesis of the flagellar apparatus and the production of virulence factors has also been observed for flhA deletion mutants in other bacteria that do not carry a $\operatorname{mog} R$ ortholog (Fleiszig et al., 2001; Carrillo et al., 2004). However, the effect on toxin production observed following deletion of $f h A$ or $f h F$ was clearly not replicated in the fla $A B$ deletion mutant, showing that not all deletions in the motility locus affect toxin synthesis and/or transport.

The observed effects of MogR on toxin production and virulence-related phenotypes could be conferred through direct regulation, as potentially indicated through in vitro binding to the $h b l$ upstream region, or indirectly through repression of genes in the motility locus, such as e.g., flhA and/or flhF, or both. As plcR expression was not affected by MogR overexpression, and only six out of the 28 genes comprising the PlcR regulon (Gohar et al., 2008) were differentially expressed in the microarray analysis, the observed repression of virulence by $\mathrm{Mog} R$ is probably not due to direct repression of the virulence gene activator PlcR. Conversely, MogR was not identified as a member of the $\mathrm{PlcR}$ regulon, despite in silico analyses identifying a PlcR box upstream of $\operatorname{mog} R$ (Gohar et al., 2008; Figure 5A). However, it is possible that crosstalk between the $\operatorname{Mog} R$ and $\mathrm{PlcR}$ regulators may nevertheless occur, at least under certain circumstances, as in many cases microarray experiments conducted under a given set of conditions fail to identify all members of a regulon. This was for example the case for the transcriptional regulator NprR, which was initially not considered part of the PlcR regulon despite the presence of a $\mathrm{PlcR}$ box in the promoter region (Gohar et al., 2008), but which was nevertheless later found to be positively controlled by PlcR (Dubois et al., 2013). In the current study, NprR was repressed by MogR overexpression. Like for virulence, motility also appears to be oppositely regulated by $\mathrm{MogR}$ and $\mathrm{PlcR}$, as motility and motility gene expression was reduced in a plcR mutant (Gohar et al., 2002, 2008). The existence and nature of putative molecular crosstalk mechanisms involving PlcR and MogR will require further study.

When employing a $\triangle$ fla $A B$ genetic background to compare the effect of MogR overexpression on biofilm formation, relative to empty vector and $\operatorname{Mog} \mathrm{R}^{Q N} \rightarrow A A$ overexpression controls, a significant increase in biofilm formation was observed by MogR overexpression. In line with this, the transcriptional profiling experiments showed upregulated expression of the biofilm anti-repressor sinI, and BTB_RS26935 located in a putative polysaccharide locus previously shown to be implicated in the formation of the biofilm matrix in some $B$. cereus strains (Hayrapetyan et al., 2015; Okshevsky et al., 2017). Moreover, LC-MS/MS quantitation indicated a slight increase in cellular c-di-GMP upon MogR overexpression, which is linked to increased biofilm formation in B. thuringiensis 407 (Fagerlund et al., 2016; Fu et al., 2018). A microarray experiment analyzing the effect of $B$. thuringiensis 407 overexpressing the c-di-GMP synthesizing protein CdgF relative to an empty vector control strain (Fagerlund et al., 2016; A. Fagerlund, unpublished data deposited in the ArrayExpress database, accession no. E-MTAB-8898) showed that the expression of the biofilm regulators $s p o 0 A$ and $\sin I$ were upregulated and the transcriptional regulator $\operatorname{cod} Y$ was downregulated at high levels of c-di-GMP, all paralleling an increase in biofilm formation (Pflughoeft et al., 2011; Lindbäck et al., 2012; Fagerlund et al., 2014). Taken together, these experiments provide strong indication that $\operatorname{MogR}$, directly or indirectly promotes biofilm formation in $B$. thuringiensis 407, a phenotype in line with the role of the protein in promoting sessility and repressing toxicity.

In L. monocytogenes, MogR activity is controlled by its antirepressor GmaR (Kamp and Higgins, 2009). GmaR expression is halted when L. monocytogenes experiences $37^{\circ} \mathrm{C}$, which allows MogR to repress flagellar synthesis during human infection. The gmaR gene is not present in most $B$. cereus group genomes, in line with $\operatorname{mog} R$ appearing to be regulated in a growth-dependent 
but temperature-independent manner in B. thuringiensis 407 . It is however interesting to note that a $g m a R$ ortholog is found in at least twelve sequenced $B$. cereus group strains, including all hitherto characterized strains of the thermotolerant species B. cytotoxicus, perhaps reflecting a need for strains in this phylogenetic group (group VII) to regulate flagellin synthesis at different temperatures. Most B. anthracis strains also harbor a copy of $g m a R$, which however is truncated and rendered nonfunctional due to mutation. Uncharacteristically, an apparently full-length gmaR copy was identified in the genome of $B$. cereus VD184, an environmental soil isolate belonging to phylogenetic cluster IV (Hoton et al., 2009; Jalasvuori et al., 2013), as well as B. cereus strains RU36C, F528-94, MB.22, B4118 and FSL W80932, and Bacillus wiedmannii FSL P4-0569, for which optimal growth temperatures are not known.

In conclusion, $\operatorname{Mog} \mathrm{R}$ is a key regulator of motility in B. thuringiensis 407, a function which is probably conserved across the motile species in the $B$. cereus group. Most importantly however, both microarray experiments, protein expression analyses, biofilm screening results, and the fact that the comparative genomics analyses showed $\operatorname{mog} R$ to be evolutionary retained in the non-motile species $B$. mycoides, $B$. pseudomycoides, and B. anthracis, as well as expressed in B. anthracis, speaks to the MogR transcriptional regulator serving additional functions in $B$. cereus group bacteria, beyond those identified in L. monocytogenes. In this respect it is interesting to note that all attempts to produce a gene deletion mutant in $\operatorname{mog} R$ in $B$. thuringiensis 407 were unsuccessful, and we cannot rule out the possibility of $\operatorname{mog} R$ constituting an essential gene in the $B$. cereus group. From the analyses performed in this study, it is tempting to speculate that MogR may serve as part of a molecular system coordinating motility, virulence, and biofilm formation, and possibly additional phenotypes. Biofilm formation and motility are reciprocally regulated in a number of bacterial species, including $B$. cereus group bacteria, by the second messenger c-di-GMP (Hengge, 2009; Fagerlund et al., 2016; Jenal et al., 2017; Fu et al., 2018), and several transcriptional regulators in both the B. cereus group and L. monocytogenes are known to have overlapping functions in regulation of virulence and biofilm formation (Hsueh et al., 2006; Lemon et al., 2010; Pflughoeft et al., 2011; Frenzel et al., 2012; Lindbäck et al., 2012; Fagerlund et al., 2014; Slamti et al., 2015; Böhm et al., 2016). It thus appears that, in the $B$. cereus group, there is substantial cross-regulation between motility, virulence, and biofilm formation, involving a multitude of regulatory networks based on both c-di-GMP and transcription factors (PlcR, MogR, NprR).

\section{DATA AVAILABILITY STATEMENT}

The microarray data comparing overexpression of MogR with the empty vector control is available in the ArrayExpress database (www.ebi.ac.uk/arrayexpress) under accession number E-MTAB7633, and the $\mathrm{CdgF}$ overexpression experiment has accession number E-MTAB-8898.

\section{AUTHOR CONTRIBUTIONS}

$O \varnothing$ and AF contributed to conception and design of the study. VS performed EMSA, motility assays, Western immunoblotting, and biofilm assays. VS and AF performed RT-qPCR. VS, MJ, and $\mathrm{AF}$ performed cloning and mutagenesis. MJ performed the microarray experiment. SF performed growth experiments. IH performed AFM. TL performed cytotoxicity assays. CN-L performed the G. mellonella infection experiments. AF performed bioinformatic, microarray, and statistical analyses. NT performed bioinformatic analysis of the subgroup I genomes. VS, $O \varnothing$, and AF wrote the first draft of the manuscript. TL, IH, and $\mathrm{CN}-\mathrm{L}$ wrote sections of the manuscript. All authors contributed to data analysis, read, and approved the final manuscript.

\section{FUNDING}

This work was funded by a project grant from the Research Council of Norway to $O \varnothing$ through the FUGE II Program (channel 3 grant; project number 183421), the Jahre Foundation, and by internal grants from the Department of Pharmacy, University of Oslo to $\mathrm{O} \emptyset$. The open access article processing charge was funded by Nofima.

\section{ACKNOWLEDGMENTS}

We are very grateful to Erwin Märtlbauer, Ludwig-MaximiliansUniversität, Germany, for monoclonal antibodies against $\mathrm{Hbl}$ and Nhe, and to Cecilie From, Norwegian University of Life Sciences, Norway, for anti-flagellin antibodies. We gratefully thank Didier Lereclus, INRA, France for the E. coli/Bacillus shuttle vector pHT304- $\mathrm{P}_{x y l}$, and Michel Gohar, INRA, France, for the B. thuringiensis $407 \triangle$ flaAB strain. We thank Christophe Buisson, INRA, France, for performing force-feeding of insect larvae, and Marthe P. Parmer and Leon Reubsaet, School of Pharmacy, University of Oslo, Norway, for quantitation of cellular c-di-GMP levels. This manuscript has been released as a pre-print at bioRxiv (Smith et al., 2020).

\section{SUPPLEMENTARY MATERIAL}

The Supplementary Material for this article can be found online at: https://www.frontiersin.org/articles/10.3389/fmicb. 2020.610650/full\#supplementary-material 


\section{REFERENCES}

Abràmoff, M. D., Magalhães, P. J., and Ram, S. J. (2004). Image processing with ImageJ. Biophotonics Int. 11, 36-42.

Altschul, S. F., Gish, W., Miller, W., Myers, E. W., and Lipman, D. J. (1990). Basic local alignment search tool. J. Mol. Biol. 215, 403-410. doi: 10.1016/s00222836(05)80360-2

Altschul, S. F., Madden, T. L., Schäffer, A. A., Zhang, J., Zhang, Z., Miller, W., et al. (1997). Gapped BLAST and PSI-BLAST: a new generation of protein database search programs. Nucleic Acids Res. 25, 3389-3402. doi: 10.1093/nar/25.17.3389

Arantes, O., and Lereclus, D. (1991). Construction of cloning vectors for Bacillus thuringiensis. Gene 108, 115-119. doi: 10.1016/0378-1119(91)90495-w

Auger, S., Krin, E., Aymerich, S., and Gohar, M. (2006). Autoinducer 2 affects biofilm formation by Bacillus cereus. Appl. Environ. Microbiol. 72, 937-941. doi: 10.1128/aem.72.1.937-941.2006

Barbe, V., Cruveiller, S., Kunst, F., Lenoble, P., Meurice, G., Sekowska, A., et al. (2009). From a consortium sequence to a unified sequence: the Bacillus subtilis 168 reference genome a decade later. Microbiology 155, 1758-1775. doi: 10. 1099/mic.0.027839-0

Bazinet, A. L. (2017). Pan-genome and phylogeny of Bacillus cereus sensu lato. BMC Evol. Biol. 17:176. doi: 10.1186/s12862-017-1020-1

Bergman, N. H., Anderson, E. C., Swenson, E. E., Niemeyer, M. M., Miyoshi, A. D., and Hanna, P. C. (2006). Transcriptional profiling of the Bacillus anthracis life cycle in vitro and an implied model for regulation of spore formation. J. Bacteriol. 188, 6092-6100. doi: 10.1128/jb.00723-06

Böhm, M. E., Krey, V. M., Jeßberger, N., Frenzel, E., and Scherer, S. (2016). Comparative bioinformatics and experimental analysis of the intergenic regulatory regions of Bacillus cereus $h b l$ and nhe enterotoxin operons and the impact of CodY on virulence heterogeneity. Front. Microbiol. 7:768. doi: 10.3389/fmicb.2016.00768

Bottone, E. J. (2010). Bacillus cereus, a volatile human pathogen. Clin. Microbiol. Rev. 23, 382-398. doi: 10.1128/cmr.00073-09

Bouillaut, L., Ramarao, N., Buisson, C., Gilois, N., Gohar, M., Lereclus, D., et al. (2005). FlhA influences Bacillus thuringiensis PlcR-regulated gene transcription, protein production, and virulence. Appl. Environ. Microbiol. 71, 8903-8910. doi: 10.1128/aem.71.12.8903-8910.2005

Branda, S. S., González-Pastor, J. E., Ben-Yehuda, S., Losick, R., and Kolter, R. (2001). Fruiting body formation by Bacillus subtilis. Proc. Natl. Acad. Sci. U.S.A. 98, 11621-11626. doi: 10.1073/pnas.191384198

Carrillo, C. D., Taboada, E., Nash, J. H., Lanthier, P., Kelly, J., Lau, P. C., et al. (2004). Genome-wide expression analyses of Campylobacter jejuni NCTC11168 reveals coordinate regulation of motility and virulence by flhA. J. Biol. Chem. 279, 20327-20338. doi: 10.1074/jbc.M401134200

Celandroni, F., Salvetti, S., Senesi, S., and Ghelardi, E. (2014). Bacillus thuringiensis membrane-damaging toxins acting on mammalian cells. FEMS Microbiol. Lett. 361, 95-103. doi: 10.1111/1574-6968.12615

Chaban, B., Hughes, H. V., and Beeby, M. (2015). The flagellum in bacterial pathogens: for motility and a whole lot more. Semin. Cell Dev. Biol. 46, 91-103. doi: 10.1016/j.semcdb.2015.10.032

Chiara, M., Caruso, M., D’Erchia, A. M., Manzari, C., Fraccalvieri, R., Goffredo, E., et al. (2015). Comparative genomics of Listeria sensu lato: genus-wide differences in evolutionary dynamics and the progressive gain of complex, potentially pathogenicity-related traits through lateral gene transfer. Genome Biol. Evol. 7, 2154-2172. doi: 10.1093/gbe/evv131

Cutting, S. M. (2011). Bacillus probiotics. Food Microbiol. 28, 214-220. doi: 10. 1016/j.fm.2010.03.007

Damgaard, P. H. (1995). Diarrhoeal enterotoxin production by strains of Bacillus thuringiensis isolated from commercial Bacillus thuringiensis-based insecticides. FEMS Immunol. Med. Microbiol. 12, 245-250. doi: 10.1111/j.1574695X.1995.tb00199.x

Damgaard, P. H., Granum, P. E., Bresciani, J., Torregrossa, M. V., Eilenberg, J., and Valentino, L. (1997). Characterization of Bacillus thuringiensis isolated from infections in burn wounds. FEMS Immunol. Med. Microbiol. 18, 47-53. doi: 10.1111/j.1574-695X.1997.tb01026.x

Dietrich, R., Fella, C., Strich, S., and Märtlbauer, E. (1999). Production and characterization of monoclonal antibodies against the hemolysin BL enterotoxin complex produced by Bacillus cereus. Appl. Environ. Microbiol. 65, 4470-4474. doi: 10.1128/AEM.65.10.4470-4474.1999
Dietrich, R., Moravek, M., Bürk, C., Granum, P. E., and Märtlbauer, E. (2005). Production and characterization of antibodies against each of the three subunits of the Bacillus cereus nonhemolytic enterotoxin complex. Appl. Environ. Microbiol. 71, 8214-8220. doi: 10.1128/aem.71.12.8214-8220.2005

Dubois, T., Faegri, K., Perchat, S., Lemy, C., Buisson, C., Nielsen-LeRoux, C., et al. (2012). Necrotrophism is a quorum-sensing-regulated lifestyle in Bacillus thuringiensis. PLoS Pathog. 8:e1002629. doi: 10.1371/journal.ppat.1002629

Dubois, T., Perchat, S., Verplaetse, E., Gominet, M., Lemy, C., Aumont-Nicaise, M., et al. (2013). Activity of the Bacillus thuringiensis NprR-NprX cell-cell communication system is co-ordinated to the physiological stage through a complex transcriptional regulation. Mol. Microbiol. 88, 48-63. doi: 10.1111/ mmi.12168

Erhardt, M., Namba, K., and Hughes, K. T. (2010). Bacterial nanomachines: the flagellum and type III injectisome. Cold Spring Harb. Perspect. Biol. 2:a000299. doi: 10.1101/cshperspect.a000299

Fagerlund, A., Dubois, T., Økstad, O. A., Verplaetse, E., Gilois, N., Bennaceur, I., et al. (2014). SinR controls enterotoxin expression in Bacillus thuringiensis biofilms. PLoS One 9:e87532. doi: 10.1371/journal.pone.0087532

Fagerlund, A., Lindbäck, T., and Granum, P. E. (2010). Bacillus cereus cytotoxins $\mathrm{Hbl}$, Nhe and CytK are secreted via the Sec translocation pathway. BMC Microbiol. 10:304. doi: 10.1186/1471-2180-10-304

Fagerlund, A., Smith, V., Røhr, Å. K., Lindbäck, T., Parmer, M. P., Andersson, K. K., et al. (2016). Cyclic diguanylate regulation of Bacillus cereus group biofilm formation. Mol. Microbiol. 101, 471-494. doi: 10.1111/mmi.13405

Fagerlund, A., Ween, O., Lund, T., Hardy, S. P., and Granum, P. E. (2004). Genetic and functional analysis of the cytK family of genes in Bacillus cereus. Microbiology 150, 2689-2697. doi: 10.1099/mic.0.26975-0

Fedhila, S., Daou, N., Lereclus, D., and Nielsen-LeRoux, C. (2006). Identification of Bacillus cereus internalin and other candidate virulence genes specifically induced during oral infection in insects. Mol. Microbiol. 62, 339-355. doi: 10.1111/j.1365-2958.2006.05362.x

Finke, S., Fagerlund, A., Smith, V., Krogstad, V., Zhang, M. S., Saragliadis, A., et al. (2019). Bacillus thuringiensis CbpA is a collagen binding cell surface protein under c-di-GMP control. Cell Surf. 5:100032. doi: 10.1016/j.tcsw.2019.100032

Fleiszig, S. M., Arora, S. K., Van, R., and Ramphal, R. (2001). FlhA, a component of the flagellum assembly apparatus of Pseudomonas aeruginosa, plays a role in internalization by corneal epithelial cells. Infect. Immun. 69, 4931-4937. doi: 10.1128/iai.69.8.4931-4937.2001

Frenzel, E., Doll, V., Pauthner, M., Lücking, G., Scherer, S., and Ehling-Schulz, M. (2012). CodY orchestrates the expression of virulence determinants in emetic Bacillus cereus by impacting key regulatory circuits. Mol. Microbiol. 85, 67-88. doi: 10.1111/j.1365-2958.2012.08090.x

Fu, Y., Yu, Z., Liu, S., Chen, B., Zhu, L., Li, Z., et al. (2018). c-di-GMP regulates various phenotypes and insecticidal activity of Gram-positive Bacillus thuringiensis. Front. Microbiol. 9:45. doi: 10.3389/fmicb.2018.00045

Gaviria Rivera, A. M., Granum, P. E., and Priest, F. G. (2000). Common occurrence of enterotoxin genes and enterotoxicity in Bacillus thuringiensis. FEMS Microbiol. Lett. 190, 151-155. doi: 10.1111/j.1574-6968.2000.tb09278.x

Ghelardi, E., Celandroni, F., Salvetti, S., Beecher, D. J., Gominet, M., Lereclus, D., et al. (2002). Requirement of flhA for swarming differentiation, flagellin export, and secretion of virulence-associated proteins in Bacillus thuringiensis. J. Bacteriol. 184, 6424-6433. doi: 10.1128/jb.184.23.6424-6433. 2002

Ghelardi, E., Celandroni, F., Salvetti, S., Ceragioli, M., Beecher, D. J., Senesi, S., et al. (2007a). Swarming behavior of and hemolysin BL secretion by Bacillus cereus. Appl. Environ. Microbiol. 73, 4089-4093. doi: 10.1128/aem.02345-06

Ghelardi, E., Celandroni, F., Salvetti, S., Fiscarelli, E., and Senesi, S. (2007b). Bacillus thuringiensis pulmonary infection: critical role for bacterial membranedamaging toxins and host neutrophils. Microbes Infect. 9, 591-598. doi: 10.1016/ j.micinf.2007.02.001

Glaser, P., Frangeul, L., Buchrieser, C., Rusniok, C., Amend, A., Baquero, F., et al. (2001). Comparative genomics of Listeria species. Science 294, 849-852. doi: 10.1126/science.1063447

Gohar, M., Faegri, K., Perchat, S., Ravnum, S., Økstad, O. A., Gominet, M., et al. (2008). The PlcR virulence regulon of Bacillus cereus. PLoS One 3:e2793. doi: 10.1371/journal.pone.0002793

Gohar, M., Gilois, N., Graveline, R., Garreau, C., Sanchis, V., and Lereclus, D. (2005). A comparative study of Bacillus cereus, Bacillus thuringiensis and 
Bacillus anthracis extracellular proteomes. Proteomics 5, 3696-3711. doi: 10. 1002/pmic.200401225

Gohar, M., Økstad, O. A., Gilois, N., Sanchis, V., Kolstø, A. B., and Lereclus, D. (2002). Two-dimensional electrophoresis analysis of the extracellular proteome of Bacillus cereus reveals the importance of the PlcR regulon. Proteomics 2, 784-791. doi: 10.1002/1615-9861(200206)2:6<784::aid-prot784>3.0.co;2-r

Gründling, A., Burrack, L. S., Bouwer, H. G., and Higgins, D. E. (2004). Listeria monocytogenes regulates flagellar motility gene expression through MogR, a transcriptional repressor required for virulence. Proc. Natl. Acad. Sci. U.S.A. 101, 12318-12323. doi: 10.1073/pnas.0404924101

Guinebretière, M. H., Auger, S., Galleron, N., Contzen, M., De Sarrau, B., De Buyser, M. L., et al. (2013). Bacillus cytotoxicus sp. nov. is a novel thermotolerant species of the Bacillus cereus group occasionally associated with food poisoning. Int. J. Syst. Evol. Microbiol. 63, 31-40. doi: 10.1099/ijs.0.030627-0

Guinebretière, M. H., Thompson, F. L., Sorokin, A., Normand, P., Dawyndt, P., Ehling-Schulz, M., et al. (2008). Ecological diversification in the Bacillus cereus group. Environ. Microbiol. 10, 851-865. doi: 10.1111/j.1462-2920.2007.01495.x

Han, L. L., Shao, H. H., Liu, Y. C., Liu, G., Xie, C. Y., Cheng, X. J., et al. (2017). Transcriptome profiling analysis reveals metabolic changes across various growth phases in Bacillus pumilus BA06. BMC Microbiol. 17:156. doi: 10.1186/ s12866-017-1066-7

Harlow, E. D. L. (1988). Antibodies: A Laboratory Manual. Cold Spring Harbor, NY: Cold Spring Harbor Laboratory.

Hayashi, F., Smith, K. D., Ozinsky, A., Hawn, T. R., Yi, E. C., Goodlett, D. R., et al. (2001). The innate immune response to bacterial flagellin is mediated by Toll-like receptor 5. Nature 410, 1099-1103. doi: 10.1038/35074106

Hayrapetyan, H., Tempelaars, M., Nierop Groot, M., and Abee, T. (2015). Bacillus cereus ATCC 14579 RpoN (sigma 54) is a pleiotropic regulator of growth, carbohydrate metabolism, motility, biofilm formation and toxin production. PLoS One 10:e0134872. doi: 10.1371/journal.pone.0134872

Hengge, R. (2009). Principles of c-di-GMP signalling in bacteria. Nat. Rev. Microbiol. 7, 263-273. doi: 10.1038/nrmicro2109

Hernandez, E., Ramisse, F., Ducoureau, J. P., Cruel, T., and Cavallo, J. D. (1998). Bacillus thuringiensis subsp. konkukian (serotype H34) superinfection: case report and experimental evidence of pathogenicity in immunosuppressed mice. J. Clin. Microbiol. 36, 2138-2139. doi: 10.1128/JCM.36.7.2138-2139.1998

Hoton, F. M., Fornelos, N., N'Guessan, E., Hu, X., Swiecicka, I., Dierick, K., et al. (2009). Family portrait of Bacillus cereus and Bacillus weihenstephanensis cereulide-producing strains. Environ. Microbiol. Rep. 1, 177-183. doi: 10.1111/ j.1758-2229.2009.00028.x

Houry, A., Briandet, R., Aymerich, S., and Gohar, M. (2010). Involvement of motility and flagella in Bacillus cereus biofilm formation. Microbiology 156, 1009-1018. doi: 10.1099/mic.0.034827-0

Hsueh, Y. H., Somers, E. B., Lereclus, D., and Wong, A. C. L. (2006). Biofilm formation by Bacillus cereus is influenced by PlcR, a pleiotropic regulator. Appl. Environ. Microbiol. 72, 5089-5092. doi: 10.1128/aem.02182-06

Ivanova, N., Sorokin, A., Anderson, I., Galleron, N., Candelon, B., Kapatral, V., et al. (2003). Genome sequence of Bacillus cereus and comparative analysis with Bacillus anthracis. Nature 423, 87-91. doi: 10.1038/nature01582

Jackson, S. G., Goodbrand, R. B., Ahmed, R., and Kasatiya, S. (1995). Bacillus cereus and Bacillus thuringiensis isolated in a gastroenteritis outbreak investigation. Lett. Appl. Microbiol. 21, 103-105. doi: 10.1111/j.1472-765x.1995.tb01017.x

Jalasvuori, M., Palmu, S., Gillis, A., Kokko, H., Mahillon, J., Bamford, J. K., et al. (2013). Identification of five novel tectiviruses in Bacillus strains: analysis of a highly variable region generating genetic diversity. Res. Microbiol. 164, 118-126. doi: 10.1016/j.resmic.2012.10.011

Jenal, U., Reinders, A., and Lori, C. (2017). Cyclic di-GMP: second messenger extraordinaire. Nat. Rev. Microbiol. 15, 271-284. doi: 10.1038/nrmicro.2016. 190

Jiménez, G., Urdiain, M., Cifuentes, A., López-Lopez, A., Blanch, A. R., Tamames, J., et al. (2013). Description of Bacillus toyonensis sp. nov., a novel species of the Bacillus cereus group, and pairwise genome comparisons of the species of the group by means of ANI calculations. Syst. Appl. Microbiol. 36, 383-391. doi: 10.1016/j.syapm.2013.04.00

Kamp, H. D., and Higgins, D. E. (2009). Transcriptional and post-transcriptional regulation of the GmaR antirepressor governs temperature-dependent control of flagellar motility in Listeria monocytogenes. Mol. Microbiol. 74, 421-435. doi: 10.1111/j.1365-2958.2009.06874.x
Kamp, H. D., and Higgins, D. E. (2011). A protein thermometer controls temperature-dependent transcription of flagellar motility genes in Listeria monocytogenes. PLoS Pathog. 7:e1002153. doi: 10.1371/journal.ppat.1002153

Kearns, D. B., Chu, F., Branda, S. S., Kolter, R., and Losick, R. (2005). A master regulator for biofilm formation by Bacillus subtilis. Mol. Microbiol. 55, 739-749. doi: $10.1111 / j .1365-2958.2004 .04440 . x$

Kim, M. J., Han, J. K., Park, J. S., Lee, J. S., Lee, S. H., Cho, J. I., et al. (2015). Various enterotoxin and other virulence factor genes widespread among Bacillus cereus and Bacillus thuringiensis strains. J. Microbiol. Biotechnol. 25, 872-879. doi: 10.4014/jmb.1502.02003

Klee, S. R., Brzuszkiewicz, E. B., Nattermann, H., Brüggemann, H., Dupke, S., Wollherr, A., et al. (2010). The genome of a Bacillus isolate causing anthrax in chimpanzees combines chromosomal properties of B. cereus with B. anthracis virulence plasmids. PLoS One 5:e10986. doi: 10.1371/journal.pone.0010986

Kolstø, A. B., Tourasse, N. J., and Økstad, O. A. (2009). What sets Bacillus anthracis apart from other Bacillus species? Annu. Rev. Microbiol. 63, 451-476. doi: 10.1146/annurev.micro.091208.073255

Kristoffersen, S. M., Ravnum, S., Tourasse, N. J., Økstad, O. A., Kolstø, A. B., and Davies, W. (2007). Low concentrations of bile salts induce stress responses and reduce motility in Bacillus cereus ATCC 14579. J. Bacteriol. 189, 5302-5313. doi: $10.1128 /$ jb.00239-07

Larsen, T. S., and Krogh, A. (2003). EasyGene - a prokaryotic gene finder that ranks ORFs by statistical significance. BMC Bioinformatics 4:21. doi: 10.1186/14712105-4-21

Lecadet, M. M., Blondel, M. O., and Ribier, J. (1980). Generalized transduction in Bacillus thuringiensis var. berliner 1715 using bacteriophage CP-54Ber. J. Gen. Microbiol. 121, 203-212. doi: 10.1099/00221287-121-1-203

Lemon, K. P., Freitag, N. E., and Kolter, R. (2010). The virulence regulator PrfA promotes biofilm formation by Listeria monocytogenes. J. Bacteriol. 192, 3969-3976. doi: 10.1128/jb.00179-10

Lereclus, D., Arantès, O., Chaufaux, J., and Lecadet, M. (1989). Transformation and expression of a cloned delta-endotoxin gene in Bacillus thuringiensis. FEMS Microbiol. Lett. 51, 211-217. doi: 10.1016/0378-1097(89)90511-9

Lereclus, D., Lecadet, M. M., Ribier, J., and Dedonder, R. (1982). Molecular relationships among plasmids of Bacillus thuringiensis: conserved sequences through 11 crystalliferous strains. Mol. Gen. Genet. 186, 391-398. doi: 10.1007/ BF00729459

Li, B., Yue, Y., Yuan, Z., Zhang, F., Li, P., Song, N., et al. (2017). Salmonella STM1697 coordinates flagella biogenesis and virulence by restricting flagellar master protein FlhD4C2 from recruiting RNA polymerase. Nucleic Acids Res. 45, 9976-9989. doi: 10.1093/nar/gkx656

Lindbäck, T., and Granum, P. E. (2006). "Detection and purification of Bacillus cereus enterotoxins," in Food-Borne Pathogens. Methods in Biotechnology, Vol. 21, ed. C. C. Adley (Totowa, NJ: Humana Press Inc), 15-26. doi: 10.1385/159259-990-7:015

Lindbäck, T., Mols, M., Basset, C., Granum, P. E., Kuipers, O. P., and Kovács, A. T. (2012). CodY, a pleiotropic regulator, influences multicellular behaviour and efficient production of virulence factors in Bacillus cereus. Environ. Microbiol. 14, 2233-2246. doi: 10.1111/j.1462-2920.2012.02766.x

Lindbäck, T., Økstad, O. A., Rishovd, A. L., and Kolstø, A. B. (1999). Insertional inactivation of $h b l C$ encoding the L2 component of Bacillus cereus ATCC 14579 haemolysin BL strongly reduces enterotoxigenic activity, but not the haemolytic activity against human erythrocytes. Microbiology 145, 3139-3146. doi: 10.1099/00221287-145-11-3139

Lövgren, A., Zhang, M. Y., Engström, A., and Landén, R. (1993). Identification of two expressed flagellin genes in the insect pathogen Bacillus thuringiensis subsp. alesti. J. Gen. Microbiol. 139, 21-30. doi: 10.1099/00221287-139$1-21$

Markowitz, V. M., Chen, I. M., Palaniappan, K., Chu, K., Szeto, E., Grechkin, Y., et al. (2010). The integrated microbial genomes system: an expanding comparative analysis resource. Nucleic Acids Res. 38, D382-D390. doi: 10.1093/ nar/gkp887

Masson, L., Préfontaine, G., and Brousseau, R. (1989). Transformation of Bacillus thuringiensis vegetative cells by electroporation. FEMS Microbiol. Lett. 51, 273-277. doi: 10.1016/0378-1097(89)90409-6

Mazzantini, D., Celandroni, F., Salvetti, S., Gueye, S. A., Lupetti, A., Senesi, S., et al. (2016). FlhF is required for swarming motility and full pathogenicity of Bacillus cereus. Front. Microbiol. 7:1644. doi: 10.3389/fmicb.2016.01644 
Mazzantini, D., Fonnesu, R., Celandroni, F., Calvigioni, M., Vecchione, A., Mrusek, D., et al. (2020). GTP-dependent FlhF homodimer supports secretion of a hemolysin in Bacillus cereus. Front. Microbiol. 11:879. doi: 10.3389/fmicb.2020. 00879

Nakamura, L. K. (1998). Bacillus pseudomycoides sp. nov. Int. J. Syst. Bacteriol. 48, 1031-1035. doi: 10.1099/00207713-48-3-1031

Okshevsky, M., Louw, M. G., Lamela, E. O., Nilsson, M., Tolker-Nielsen, T., and Meyer, R. L. (2017). A transposon mutant library of Bacillus cereus ATCC 10987 reveals novel genes required for biofilm formation and implicates motility as an important factor for pellicle-biofilm formation. MicrobiologyOpen 7:e00552. doi: $10.1002 / \mathrm{mbo} 3.552$

Pfaffl, M. W. (2001). A new mathematical model for relative quantification in real-time RT-PCR. Nucleic Acids Res. 29:e45. doi: 10.1093/nar/29.9.e45

Pflughoeft, K. J., Sumby, P., and Koehler, T. M. (2011). Bacillus anthracis sin locus and regulation of secreted proteases. J. Bacteriol. 193, 631-639. doi: 10.1128/jb. 01083-10

Ramarao, N., and Lereclus, D. (2006). Adhesion and cytotoxicity of Bacillus cereus and Bacillus thuringiensis to epithelial cells are FlhA and PlcR dependent, respectively. Microbes Infect. 8, 1483-1491. doi: 10.1016/j.micinf.2006.01.005

Ramírez Santos, J., Contreras Ferrat, G., and Gómez Eichelmann, M. C. (2005). [Stationary phase in Escherichia coli]. Rev. Latinoam. Microbiol. 47, 92-101.

Reiter, L., Kolstø, A. B., and Piehler, A. P. (2011). Reference genes for quantitative, reverse-transcription PCR in Bacillus cereus group strains throughout the bacterial life cycle. J. Microbiol. Methods 86, 210-217. doi: 10.1016/j.mimet. 2011.05.006

Salamitou, S., Agaisse, H., and Lereclus, D. (1997). A genetic system that reports transient activation of genes in Bacillus. Gene 202, 121-126. doi: 10.1016/s03781119(97)00462-9

Salvetti, S., Faegri, K., Ghelardi, E., Kolstø, A. B., and Senesi, S. (2011). Global gene expression profile for swarming Bacillus cereus bacteria. Appl. Environ. Microbiol. 77, 5149-5156. doi: 10.1128/aem.00245-11

Salvetti, S., Ghelardi, E., Celandroni, F., Ceragioli, M., Giannessi, F., and Senesi, S. (2007). FlhF, a signal recognition particle-like GTPase, is involved in the regulation of flagellar arrangement, motility behaviour and protein secretion in Bacillus cereus. Microbiology 153, 2541-2552. doi: 10.1099/mic.0.2006/005 553-0

Samples, J. R., and Buettner, H. (1983). Corneal ulcer caused by a biologic insecticide (Bacillus thuringiensis). Am. J. Ophthalmol. 95, 258-260. doi: 10. 1016/0002-9394(83)90028-4

Shen, A., and Higgins, D. E. (2006). The MogR transcriptional repressor regulates nonhierarchal expression of flagellar motility genes and virulence in Listeria monocytogenes. PLoS Pathog. 2:e30. doi: 10.1371/journal.ppat.0020030

Shen, A., Higgins, D. E., and Panne, D. (2009). Recognition of AT-rich DNA binding sites by the MogR repressor. Structure 17, 769-777. doi: 10.1016/j.str. 2009.02.018

Shen, A., Kamp, H. D., Gründling, A., and Higgins, D. E. (2006). A bifunctional O-GlcNAc transferase governs flagellar motility through anti-repression. Genes Dev. 20, 3283-3295. doi: 10.1101/gad.1492606
Sheppard, A. E., Poehlein, A., Rosenstiel, P., Liesegang, H., and Schulenburg, H. (2013). Complete genome sequence of Bacillus thuringiensis strain 407 Cry. Genome Announc. 1:e00158-12. doi: 10.1128/genomeA.00158-12

Slamti, L., Lemy, C., Henry, C., Guillot, A., Huillet, E., and Lereclus, D. (2015). CodY regulates the activity of the virulence quorum sensor PlcR by controlling the import of the signaling peptide PapR in Bacillus thuringiensis. Front. Microbiol. 6:1501. doi: 10.3389/fmicb.2015.01501

Smith, T. G., and Hoover, T. R. (2009). Deciphering bacterial flagellar gene regulatory networks in the genomic era. Adv. Appl. Microbiol. 67, 257-295. doi: 10.1016/s0065-2164(08)01008-3

Smith, V., Josefsen, M., Lindbäck, T., Hegna, I. K., Finke, S., Tourasse, N. J., et al. (2020). MogR is a ubiquitous transcriptional repressor affecting motility, biofilm formation and virulence in the Bacillus cereus group. bioRxiv [Preprint] doi: 10.1101/2020.09.26.311894

Spangler, C., Böhm, A., Jenal, U., Seifert, R., and Kaever, V. (2010). A liquid chromatography-coupled tandem mass spectrometry method for quantitation of cyclic di-guanosine monophosphate. J. Microbiol. Methods 81, 226-231. doi: 10.1016/j.mimet.2010.03.020

Stenfors Arnesen, L. P., Fagerlund, A., and Granum, P. E. (2008). From soil to gut: Bacillus cereus and its food poisoning toxins. FEMS Microbiol. Rev. 32, 579-606. doi: 10.1111/j.1574-6976.2008.00112.x

Swiecicka, I., Van der Auwera, G. A., and Mahillon, J. (2006). Hemolytic and nonhemolytic enterotoxin genes are broadly distributed among Bacillus thuringiensis isolated from wild mammals. Microb. Ecol. 52, 544-551. doi: 10. 1007/s00248-006-9122-0

Tourasse, N. J., Helgason, E., Økstad, O. A., Hegna, I. K., and Kolstø, A. B. (2006). The Bacillus cereus group: novel aspects of population structure and genome dynamics. J. Appl. Microbiol. 101, 579-593. doi: 10.1111/j.1365-2672. 2006.03087.x

Twine, S. M., Reid, C. W., Aubry, A., McMullin, D. R., Fulton, K. M., Austin, J., et al. (2009). Motility and flagellar glycosylation in Clostridium difficile. J. Bacteriol. 191, 7050-7062. doi: 10.1128/jb.00861-09

Zhang, M. Y., Lövgren, A., Low, M. G., and Landén, R. (1993). Characterization of an avirulent pleiotropic mutant of the insect pathogen Bacillus thuringiensis: reduced expression of flagellin and phospholipases. Infect. Immun. 61, 4947-4

Conflict of Interest: The authors declare that the research was conducted in the absence of any commercial or financial relationships that could be construed as a potential conflict of interest.

Copyright (c) 2020 Smith, Josefsen, Lindbäck, Hegna, Finke, Tourasse, NielsenLeRoux, Økstad and Fagerlund. This is an open-access article distributed under the terms of the Creative Commons Attribution License (CC BY). The use, distribution or reproduction in other forums is permitted, provided the original author(s) and the copyright owner(s) are credited and that the original publication in this journal is cited, in accordance with accepted academic practice. No use, distribution or reproduction is permitted which does not comply with these terms. 